\title{
Omics Approaches in Adipose Tissue and Skeletal Muscle Addressing the Role of Extracellular Matrix in Obesity and Metabolic Dysfunction
}

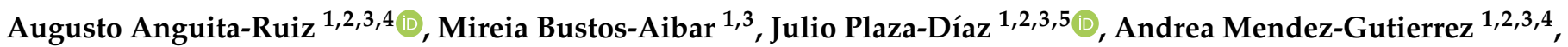 \\ Jesús Alcalá-Fdez ${ }^{6}$, , Concepción María Aguilera ${ }^{1,2,3,4, *(1)}$ and Francisco Javier Ruiz-Ojeda ${ }^{1,2,7}$ \\ 1 Department of Biochemistry and Molecular Biology II, School of Pharmacy, University of Granada, \\ 18071 Granada, Spain; augustoanguitaruiz@gmail.com (A.A.-R.); mireia251019@gmail.com (M.B.-A.); \\ jrplaza@ugr.es (J.P.-D.); andmengut@gmail.com (A.M.-G.); fruizojeda@ugr.es (F.J.R.-O.) \\ 2 Instituto de Investigación Biosanitaria IBS.GRANADA, Complejo Hospitalario Universitario de Granada, \\ 18014 Granada, Spain \\ 3 Institute of Nutrition and Food Technology "José Mataix", Center of Biomedical Research, \\ University of Granada, Avda. del Conocimiento s/n., 18016 Granada, Spain \\ 4 CIBEROBN (CIBER Physiopathology of Obesity and Nutrition), Instituto de Salud Carlos III, \\ 28029 Madrid, Spain \\ 5 Children's Hospital of Eastern Ontario Research Institute, Ottawa, ON K1H 8L1, Canada \\ 6 Department of Computer Science and Artificial Intelligence, University of Granada, 18071 Granada, Spain; \\ jalcala@decsai.ugr.es \\ Citation: Anguita-Ruiz, A.; \\ 7 RG Adipocytes and Metabolism, Institute for Diabetes and Obesity, Helmholtz Diabetes Center at Helmholtz \\ Center Munich, Neuherberg, 85764 Munich, Germany \\ * Correspondence: caguiler@ugr.es; Tel.: +34-9-5824-1000 (ext. 20314)
} Bustos-Aibar, M.; Plaza-Díaz, J.; Mendez-Gutierrez, A.; Alcalá-Fdez, J.; Aguilera, C.M.; Ruiz-Ojeda, F.J. Omics Approaches in Adipose Tissue and Skeletal Muscle Addressing the Role of Extracellular Matrix in Obesity and Metabolic Dysfunction. Int. J. Mol. Sci. 2021, 22, 2756. https://doi.org/10.3390/ijms22052756

Academic Editor:

Hironobu Yamashita

Received: 29 January 2021

Accepted: 5 March 2021

Published: 9 March 2021

Publisher's Note: MDPI stays neutral with regard to jurisdictional claims in published maps and institutional affiliations.

Copyright: (c) 2021 by the authors. Licensee MDPI, Basel, Switzerland. This article is an open access article distributed under the terms and conditions of the Creative Commons Attribution (CC BY) license (https:// creativecommons.org/licenses/by/ $4.0 /)$.
Abstract: Extracellular matrix (ECM) remodeling plays important roles in both white adipose tissue (WAT) and the skeletal muscle (SM) metabolism. Excessive adipocyte hypertrophy causes fibrosis, inflammation, and metabolic dysfunction in adipose tissue, as well as impaired adipogenesis. Similarly, disturbed ECM remodeling in SM has metabolic consequences such as decreased insulin sensitivity. Most of described ECM molecular alterations have been associated with DNA sequence variation, alterations in gene expression patterns, and epigenetic modifications. Among others, the most important epigenetic mechanism by which cells are able to modulate their gene expression is DNA methylation. Epigenome-Wide Association Studies (EWAS) have become a powerful approach to identify DNA methylation variation associated with biological traits in humans. Likewise, Genome-Wide Association Studies (GWAS) and gene expression microarrays have allowed the study of whole-genome genetics and transcriptomics patterns in obesity and metabolic diseases. The aim of this review is to explore the molecular basis of ECM in WAT and SM remodeling in obesity and the consequences of metabolic complications. For that purpose, we reviewed scientific literature including all omics approaches reporting genetic, epigenetic, and transcriptomic (GWAS, EWAS, and RNA-seq or cDNA arrays) ECM-related alterations in WAT and SM as associated with metabolic dysfunction and obesity.

Keywords: obesity; adipose tissue; extracellular matrix; skeletal muscle; genetics; epigenetic; transcriptomic

\section{Introduction}

Healthy adipose tissue expansion in obesity depends on the extracellular matrix (ECM) remodeling and reorganization to provide enough space for the enlargement of adipocytes (hypertrophy) and for the generation of new ones through adipogenesis from the precursor cells (hyperplasia). This process involves the formation of new blood vessels, which is crucial to maintain healthy adipose tissue expandability because the failure of this results in necrosis adipocytes, and hypoxia, which triggers chronic, low-grade inflammation, fibrosis, 
and lastly insulin resistance [1-4]. Regardless of the manner of expansion, variations in ECM composition substantially affect the biomechanical properties of a tissue, as is clearly detected in fibrotic diseases [5]. Fibrosis is characterized by an increase in fibril-forming ECM proteins, and one of the major adhesion receptors implicated in the regulation of this process are integrins, and its signaling in the diet-induced obese state are associated with insulin resistance in adipose tissue [4,6-8]. The inability to develop a healthy adipose tissue expansion under the excess of calories drives an ectopic fat deposition in visceral depots, liver, SM, and other cell types [9]. Furthermore, this process produces adipose tissue dysfunction that leads to changes in the ECM. Beyond these effects in adipose tissue, fat deposition in SM incites similar effects to the progressive muscle weakening associated with aging, such as insulin resistance and metabolic abnormalities [10]. Thus, besides the effect of muscle fat accumulation on insulin sensitivity, muscle lipid accumulation also promotes changes in muscle ECM [11]. Genes such as collagens, fibronectin, proteoglycans, and connective tissue growth factor are upregulated under acute lipid oversupply into the SM of healthy individuals [12]. Moreover, collagen I and collagen III are higher in SM from obese and T2D individuals [13].

In the past decade, genome-wide association studies (GWAS) have successfully identified thousands of genetic variants underlying susceptibility to complex diseases given its ability to rapidly scanning markers across the whole genome. However, the results from these studies often do not provide evidence on how the variants affect downstream pathways and lead to the disease. Hence, in the post-GWAS era, the greatest challenge lies in combining GWAS findings and functionally characterize the associations. Epigenetics is the study of heritable phenotype changes that do not involve alterations in the DNA sequence and its mechanisms control gene activity and the development of an organism [14,15]. In particular, DNA methylation is an epigenetic mechanism that modifies the function of genes and affects gene expression, and aberrant DNA methylation has been found to be associated with various complex human diseases, including obesity. EWAS have been useful in identifying disease-associated epigenetic marks for screening high-risk populations, and EWAS have identified several differentially methylated $\mathrm{CpG}$ regions related to body mass index (BMI) and other parameters of obesity. Henceforth, DNA methylation provide evidence on how molecular dysregulation can affect variety of gene types and omics approach addressing epigenetic mechanism has been increased in the last years. Indeed, DNA methylation plays an important role in adipogenesis, and adipose tissue expansion [16], and changes in DNA methylation patterns of SM in specific genes may affect to whole-body insulin sensitivity in obesity [17]. Therefore, the aim of the present review is to include the omics approach addressing genetic (GWAS), epigenetic (EWAS), or gene expression (RNA-seq and cDNA arrays) mechanisms in WAT and SM in order to understand the molecular mechanism of ECM in metabolic dysfunction associated with the obesity development.

\section{Methodology}

\subsection{Systematic Review Strategy}

This systematic review was performed according to the guidelines described by the Preferred Reporting Items for Systematic Review and Meta-Analysis (PRISMA) statement $[18,19]$; definition of the research question, literature search, data collection, evaluation, comparison, and synthesis, as well as critical analysis and findings presentation, showing the strengths and weakness of the studies analyzed. A bibliographic search strategy was conducted to identify all studies reporting ECM genetics/epigenomics/transcriptomics findings for obesity and its associated cardiometabolic phenotypes in humans. For that purpose, we considered both in vitro and in vivo studies and restricted our search to three obesity-related tissue types (blood, adipose, and SM). The electronic database consulted was NCBI/PubMed, which was automatically and iteratively mined using R environment (https: / / www.r-project.org/, accessed on 15 December 2020). Particularly, we employed an R package called "easyPubMed" (https:/ /CRAN.R-project.org/package=easyPubMed, 
accessed on 15 December 2020), which allows: (1) Query NCBI Entrez IDs and retrieve PubMed records in XML or text format, (2) Process PubMed records by extracting and aggregating data from selected fields. Prior to the search process, we identified all genes annotated in the GO and KEGG databases with terms related to the ECM (for more details regarding the ECM terms considered, please see Table S1). As a result, we identified 2186 different items. Then, we employed three Boolean searches (Table S2), corresponding to each omics of interest (genomics, epigenomics, and transcriptomics), which were iteratively run 2186 times, one time for each of the 2186 loci. Thanks to this strategy, we were able to map all research studies reporting omics findings for any of the genes that are currently known to be involved or related to the ECM. Findings were therefore identified at the locus level and organized according to ECM gene ontology terms (focusing on biological process GO and KEGG terms exclusively). By organizing associations according to the ECM structures or processes affected, we further aimed to generate new insights into the molecular basis of obesity and metabolic alterations.

\subsection{Study Selection}

In total, 634 studies were collected through the identification of records in PubMed following the different search strategies. Moreover, 31 additional articles, referenced in any chosen record and not presented in Boolean searches, were forced to inclusion, since they accomplish inclusion criteria. Inclusion criteria were studies written in English; published from April 1999 to October 2020; the presence of the selected search words in the title, abstract, or as keywords, depending on the algorithm; obesity or cardiometabolic alterations as the main outcome; investigation performed in humans (studies in animals and in vitro models were also considered, whether their aims were referred to the investigation of the human gene considered); whole-genome array-type approach; report information for the locus included in the search equation. Exclusion criteria were review articles; duplicates; and studies focused on a different gene or technology with regard to those selected for the search strategy.

The selection of studies began by screening titles, abstract and/or main manuscript for inclusion, generating a reference list of intriguing articles. A total of 345 studies were assessed and selected following the eligibility evaluation, the implementation of the exclusion criteria and fulfill inclusion criteria, including in Sections 4-6 of the present manuscript. A summary of the stages can be observed as a PRISMA flow diagram in Figure S1.

\section{Current Evidence of Adipose and SM ECM Remodeling in Obesity and Metabolic Dysfunction}

Adipose tissue ECM is composed mainly of different types of collagens (I, II, III, and IV), fibronectin, and a small amount of laminin $[20,21]$. However, several components, such as A disintegrin and metalloproteinase domain-containing protein (ADAMs), osteopontin (OPN), hyaluronan (HA), thrombospondins (THBS1), matrix metalloproteases (MMPs), and tissue inhibitor of metalloproteinases (TIMPs), play an important role in the ECM remodeling and adipose tissue function [22]. Integrins play an important role in ECM remodeling in adipose tissue, and they are the main class of tissue receptors implicated in cell-extracellular matrix interactions and cell adhesion. A recent study reveals that integrins, as the main cell surface involved in cell adhesion, interact with insulin receptor in adipocytes modulating WAT insulin sensitivity, demonstrating a new cell-matrix interaction in adipocytes [8]. Therefore, it seems that integrins and insulin signaling interact with each other and play an important role in ECM remodeling in adipose tissue. The cell surface transmembrane glycoprotein CD44 is ubiquitously expressed and it binds to the ECM, mainly OPN and HA.

Collagens are a major abundant fibrous protein in the ECM and adipocytes primarily produce collagen, though the preadipocytes, endothelial cells, and stem cells are also able to produce it. Mature adipocytes stock energy as triacylglycerol's, and this process provokes robust mechanical stress, which is relocated from the outside to the inside of 
the cell spending a lot of energy on the maintenance of the ECM [6,23,24]. Adipose tissue from obese mice (C57BL/KsJ-lepr ${ }^{d b} /$ lepr $^{d b}$ ) undergoing a high-fat diet (HFD) (40\% fat) exhibit a higher collagens content such as collagen I, III, and VI, and increased expression of procollagens I, III, V, VI, and VIII [25].

MMPs family members might be characterized into soluble collagenases (MMP1, -8 , and -13), gelatinases A and B (MMP2 and -9), stromelysin-1, 2 and 3 (MMP3, -10, and -11), matrilysin-1 and -2 (MMP7 and -26), membrane-type MMPs (MT-MMPs) (MMP14, $-15,-16,-17,-24$, and -25), and elastase (MMP12) [26]. Endothelial cells, pericytes and podocytes, fibroblasts, and myofibroblasts, and macrophages secrete MMP-2 and -9 [27]. MMP-3, MMP-11, MMP-12, MMP-13, and MMP-14 levels are upregulated in abdominal WAT, while MMP-7, MMP-9, MMP-16, MMP-24, and TIMP-4 were downregulated in mice (75\% C57/B16:25\% 129Svj genetic background) under HFD feeding (42\% Kcal as fat) [28]. On the other hand, MMP-2 and MMP-9 activity are decreased in WAT from the insulinresistant Wistar rats fed upon 30\% sucrose-rich diet, and no modifications were related to MMP plasma activity [29]. TIMPs can perform as endogenous inhibitors of MMPs that are reliable for destroying additional ECM, it is uncertain whether the useful effects of augmented TIMP or ADAMTS activities are solely due to the inhibited activity of MMPs and augmented ECM stability [30]. In particular, plasma concentrations of TIMP1 and TIMP2 are higher in patients with metabolic syndrome and diabetes [31], and gene deletion of TIMP-2 in C57Bl/ 6 mice induces obesity in HFD feeding (60\% fat) [32]. However, exercise is rather supportive in TIMP-2 modulation, improving insulin sensitivity [33].

$\mathrm{SM}$ is one of the most dynamic and plastic tissues of the human body and contains around $40 \%$ of total body weight and comprises $50-75 \%$ of all body proteins [34]. Like WAT, SM ECM remodeling is required for a proper homeostasis, which implicates a constant regulation of the synthesis vs. degradation of the main components. ECM plays an important role in muscle fiber force transmission, maintenance, and repair. The muscle ECM distribution is unique and consists of several components including endomysial (around the muscle cell), perimysial (around groups of muscle cells), and epimysial (around the whole muscle) connective tissues [35,36]. Collagen is the main protein in SM ECM, which represents between $1-10 \%$ of muscle mass dry weight [35]. There are several types of collagen-containing types I, III, IV, V, VI, XI, XII, XIV, XV, and XVIII expressed during the muscle development, although the types I and III are the predominant ones in adult endo-, peri-, and epimysium [37]. Muscle basement membrane consists primarily of a type IV collagen network, but types VI, XV, and XVIII are also present [38]. Proteoglycans are another muscle ECM component that belong to the family of small leucine-rich proteoglycans containing a core protein with attached GAG chains and include decorin, biglycan, fibromodulin, and lumican. A recent study has identified by ECM-specific mass spectrometry-based proteomics technique distinct signatures of HFD-induced protein changes between SM and liver in C57BL/6J mice. In particular, SM collagens isoforms increased upon HFD feeding ( $60 \%$ fat) and collagen $24 \alpha 1$ is associated with insulin resistance in SM. Moreover, they found that collagen $24 \alpha 1$ is highly expressed in visceral adipose tissue (VAT), but not in SAT, of obese diabetic subjects, indicating a potential pathogenic role of that collagen in obesity and T2D [39].

Alike adipose tissue, in normal SM, a delicate balance occurs between enzymes responsible for ECM synthesis and their inhibitors. Thus, the turnover of ECM is required for cell migration, myotube formation, and reorganization of the matrix during muscle adaptation. Briefly, MMPs are the major determinants in ECM remodeling and participate in the degradation of ECM components [40]. MMP-2 and MMP9 are the subclasses of metalloproteases involved in the development of obesity and insulin resistance $[36,41]$, and indeed MMP-9 plasma levels are higher, despite lower protein levels in SM under HFD ( $60 \%$ fat) fed C57BL/6J mice [41]. Furthermore, MMP-9 is released in response to myostatin, which promotes a turnover of ECM components in SM. Mostly, the balance between MMP and TIMPs is certainly critical to maintain a repair process in the context of ECM. Besides, 
MMP14 content is significant in SM due to the function in the activation of the MMP2 [36]. Therefore, MMPs and TIMPs are relevant to maintain the ECM homeostasis in muscle.

Several genes implicated in ECM remodeling in adipose tissue are also involved in SM. Integrins, which play an important function in adipose tissue [8], are implicated in myogenesis [42] and adipogenesis [43]. Thus, integrin striated muscle-specific integrin $\beta 1$-deficient C57B16/J mice exhibit decreased in AKT Ser-473 phosphorylation, glucose uptake, and glycogen synthesis, supporting the role between integrin and insulin signaling in SM [44,45]. Other ECM components such as proteoglycans [46,47], fibronectin [48,49], hepatocyte growth factor (HGF) [50,51], epidermal growth factor (EGF) [52,53], insulin-like growth factor(IGF)-1 [54,55], IGF-2 [56,57], and MMPs [58,59], among others, play crucial roles in myogenesis and adipogenesis. Hence, understanding the inter-tissue connection between WAT and SM in some common genes implicated in ECM remodeling could help to develop strategies against the metabolic disturbances in obesity. The specific molecular mechanism of ECM remodeling has been reviewed elsewhere $[4,60,61]$.

Overall, obesity drives changes in adipose and muscle ECM function and remodeling that may cause important metabolic alterations in the local and systemic metabolism. In addition, genetic variations and epigenetic changes, and in the end, the gene expression patterns can affect to those processed, which will be described in the next sections.

\section{Whole-Genome Genetic Approaches Reveal the Implication of ECM in Obesity and Metabolic Dysfunction}

In the present section, we gathered all literature findings from GWAS experiments in which sequence variation for ECM-related loci has been linked to obesity or metabolic dysfunction, although associations do not mean causative process. Findings were identified at the locus level and organized according to ECM gene ontology terms (focusing on biological process terms exclusively) (Table 1). By organizing GWAS associations according to the ECM structures or processes affected, we aimed to generate new insights into the molecular basis of obesity and metabolic alterations. In the next sections, these insights will be further integrated along with additional molecular data layers (such as associations derived from epigenomics and transcriptomics) in order to be functionally characterized. 
Table 1. Whole-genome genetics approaches reveal the implication of extracellular matrix (ECM) in obesity and metabolic dysfunction.

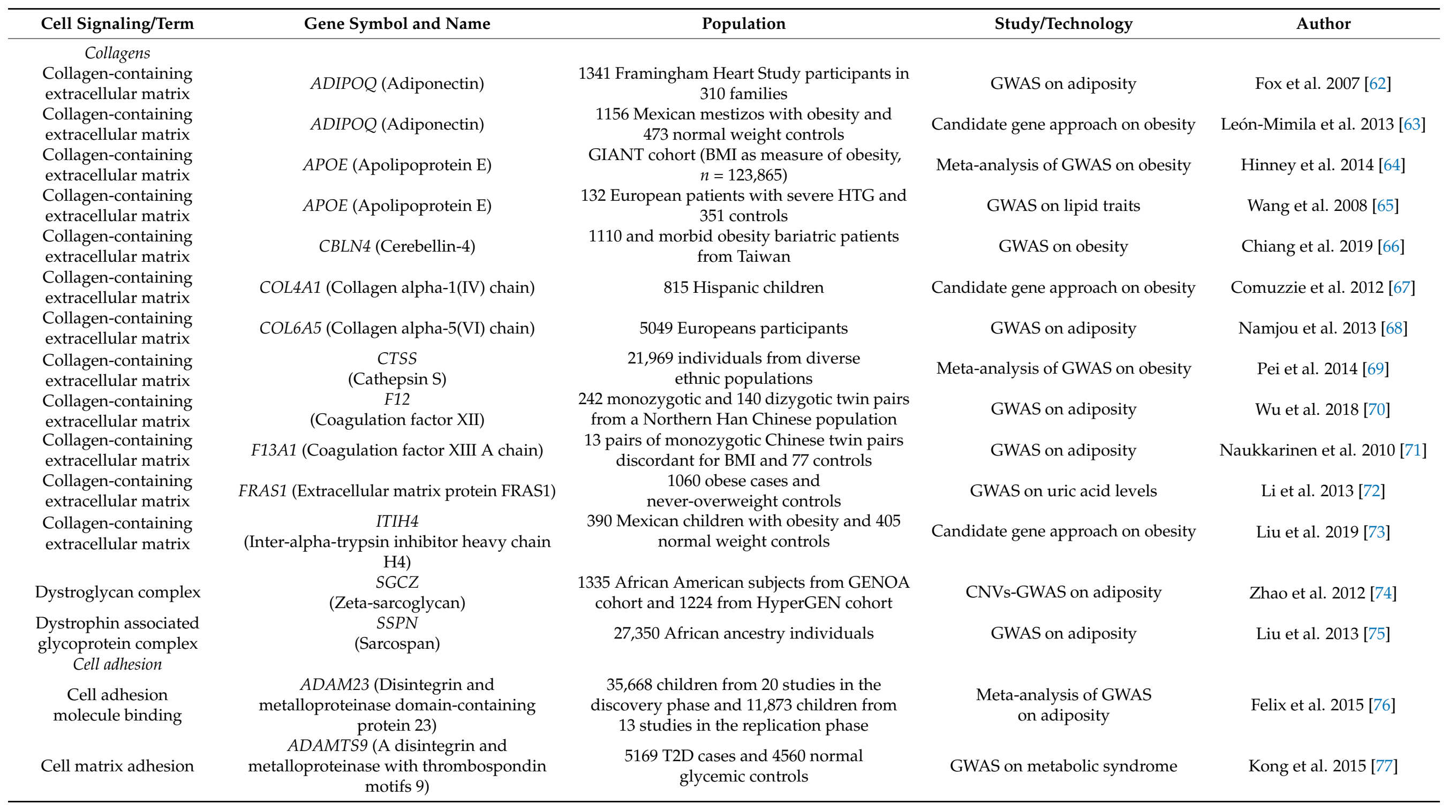


Table 1. Cont

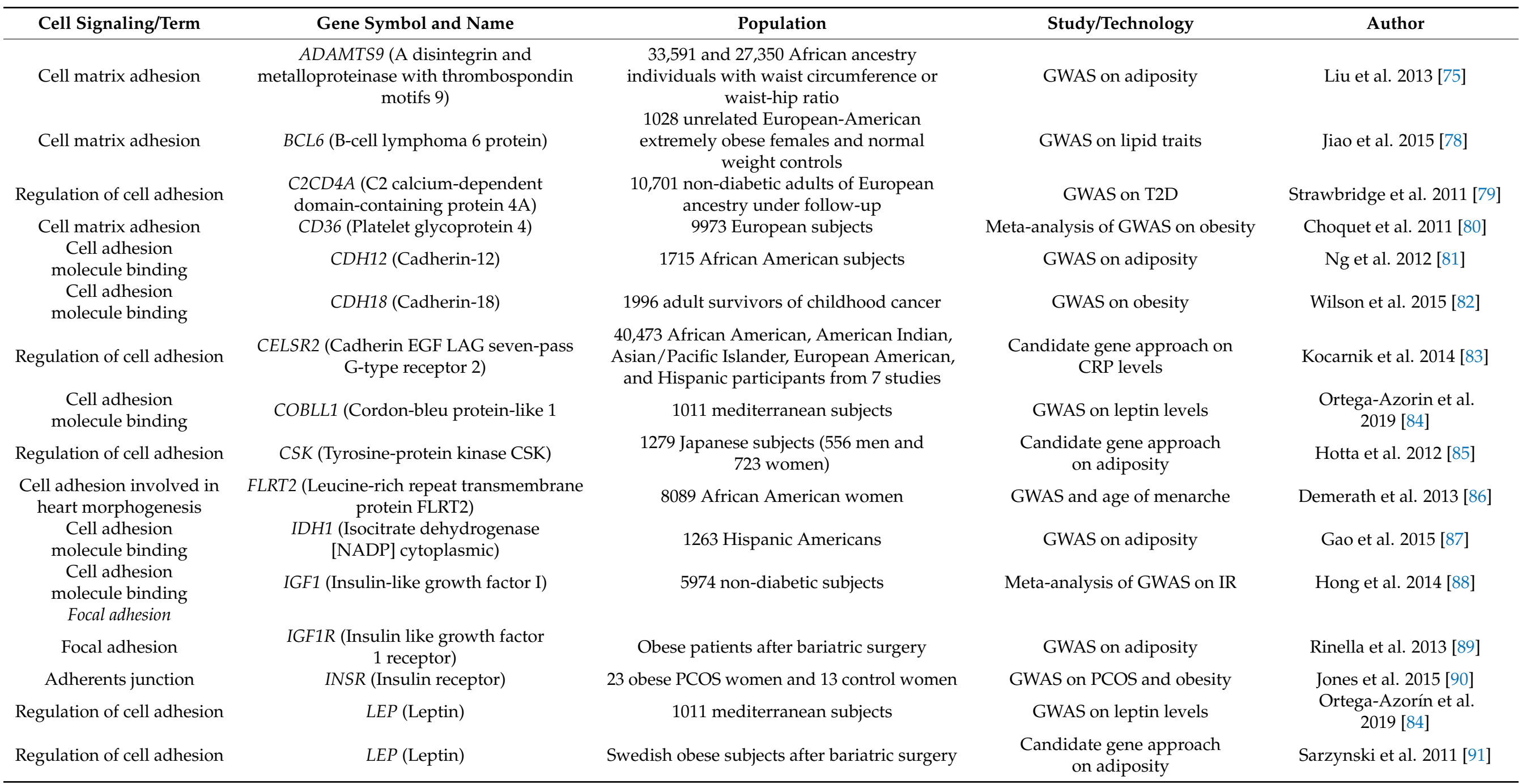


Table 1. Cont.

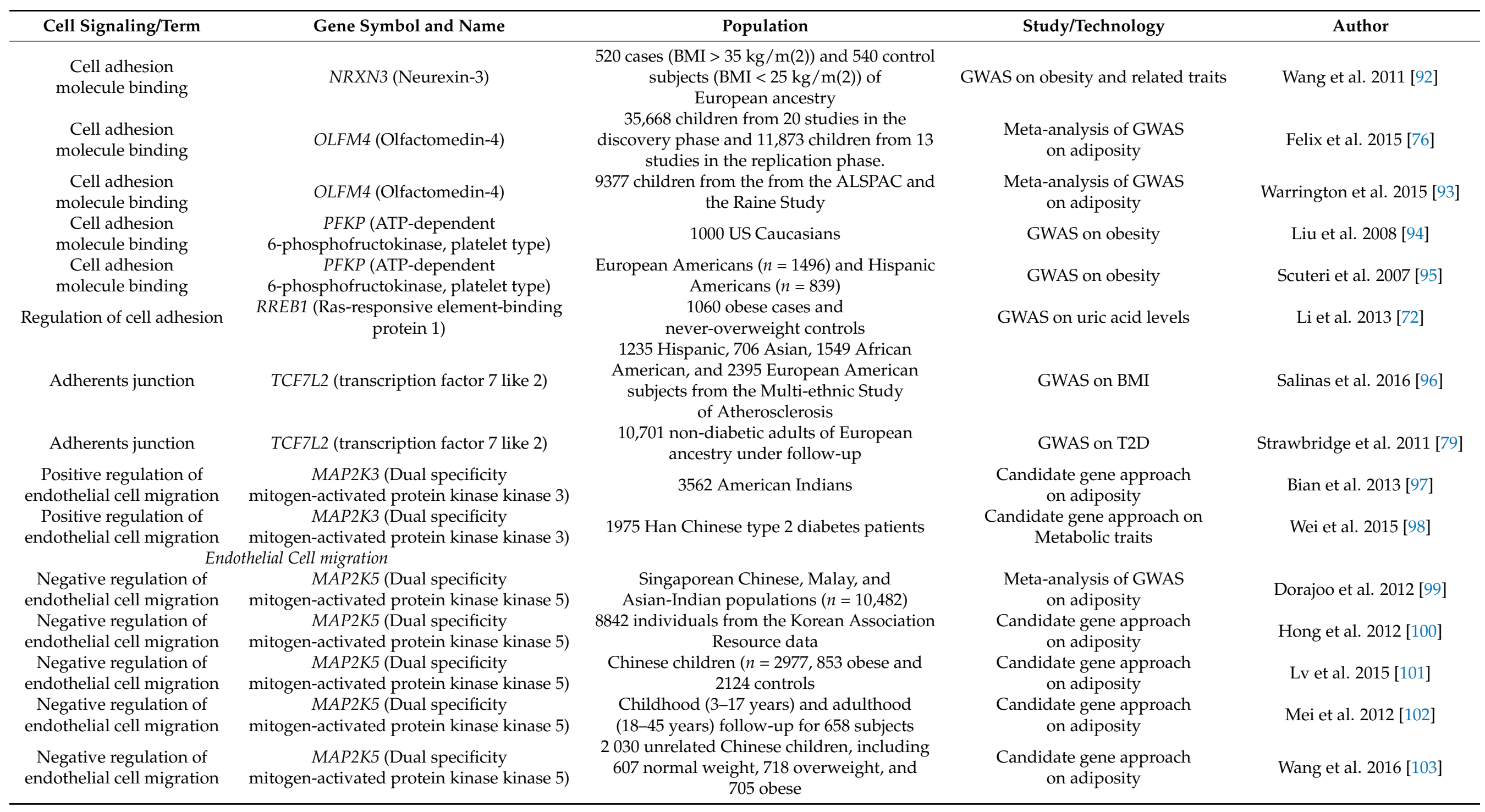


Table 1. Cont.

\begin{tabular}{|c|c|c|c|c|}
\hline Cell Signaling/Term & Gene Symbol and Name & Population & Study/Technology & Author \\
\hline $\begin{array}{l}\text { Negative regulation of } \\
\text { endothelial cell migration }\end{array}$ & $\begin{array}{c}M A P 2 K 5 \text { (Dual specificity } \\
\text { mitogen-activated protein kinase kinase } 5)\end{array}$ & $\begin{array}{l}27,715 ; 37,691 \text { and } 17,642 \text { individuals from } \\
\text { three east Asian populations }\end{array}$ & $\begin{array}{l}\text { Meta-analysis of GWAS } \\
\text { on adiposity }\end{array}$ & Wen et al. 2012 [104] \\
\hline $\begin{array}{l}\text { Positive regulation of } \\
\text { endothelial cell migration }\end{array}$ & MET (Hepatocyte growth factor receptor) & Search in GWAS catalog & $\begin{array}{l}\text { GWAS on BMI and mental } \\
\text { traits disorders }\end{array}$ & Hebebrand et al. 2018 [105] \\
\hline $\begin{array}{l}\text { Negative regulation of } \\
\text { endothelial cell migration }\end{array}$ & $\begin{array}{c}\text { PPARG (Peroxisome proliferator-activated } \\
\text { receptor gamma) }\end{array}$ & 927 non-diabetic African Americans & GWAS on IR & Chen et al. 2012 [106] \\
\hline $\begin{array}{l}\text { Negative regulation of } \\
\text { endothelial cell migration }\end{array}$ & $\begin{array}{c}\text { PPARG (Peroxisome proliferator-activated } \\
\text { receptor gamma) }\end{array}$ & $\begin{array}{c}765 \text { (556 males) from the NIMH } \\
\text { CATIE sample }\end{array}$ & $\begin{array}{l}\text { GWAS on drug-induced } \\
\text { weight-regain }\end{array}$ & Corfitsen et al. 2020 [107] \\
\hline $\begin{array}{l}\text { Negative regulation of } \\
\text { endothelial cell migration }\end{array}$ & $\begin{array}{c}\text { PPARG (Peroxisome proliferator-activated } \\
\text { receptor gamma) }\end{array}$ & Review Swedish population & Candidate gene approach on obesity & Sarzynski et al. 2011 [91] \\
\hline $\begin{array}{l}\text { Positive regulation of } \\
\text { endothelial cell migration }\end{array}$ & PROX1 (Prospero homeobox protein 1 ) & $\begin{array}{l}964 \text { chinese pregnant women with GMD and } \\
1021 \text { chinese pregnant women with normal } \\
\text { glucose tolerance }\end{array}$ & GWAS on GMD & Cao et al. 2020 [108] \\
\hline $\begin{array}{l}\text { Positive regulation of } \\
\text { endothelial cell migration }\end{array}$ & PROX1 (Prospero homeobox protein 1 ) & 756 individuals from a Mongolian sample & GWAS on obesity & Kim et al. 2013 [109] \\
\hline $\begin{array}{l}\text { Positive regulation of } \\
\text { endothelial cell migration }\end{array}$ & SIRT1 (Sirtuin 1) & 3501 Pima Indians & $\begin{array}{l}\text { Candidate gene approach on IR } \\
\text { and T2D }\end{array}$ & Dong et al. 2011 [110] \\
\hline \multicolumn{5}{|c|}{ ECM assembly and disassembly } \\
\hline $\begin{array}{l}\text { Extracellular matrix } \\
\text { structural constituent }\end{array}$ & $\begin{array}{c}\text { GP2 (Pancreatic secretory granule } \\
\text { membrane major glycoprotein GP2) }\end{array}$ & $\begin{array}{c}27,715 ; 37,691 \text { and } 17,642 \text { individuals from } \\
\text { three east Asian populations }\end{array}$ & $\begin{array}{l}\text { Meta-analysis of GWAS } \\
\text { on adiposity }\end{array}$ & Wen et al. 2012 [104] \\
\hline $\begin{array}{l}\text { Extracellular } \\
\text { matrix disassembly }\end{array}$ & IL6 (Interleukin-6) & $\begin{array}{c}16,088 \text { postmenopausal women stratified by } \\
\text { obesity status }\end{array}$ & $\begin{array}{l}\text { GWAS on Proinflammatory } \\
\text { Cytokines }\end{array}$ & Jung et al. 2020 [111] \\
\hline Extracellular matrix & $\begin{array}{l}\text { LINGO2 (Leucine-rich repeat and } \\
\text { immunoglobulin-like domain-containing } \\
\text { nogo receptor-interacting protein 2) }\end{array}$ & $\begin{array}{l}100,418 \text { adults from the single large } \\
\text { multi-ethnic Genetic Epidemiology Research } \\
\text { on Adult Health and Aging (GERA) cohort } \\
\text { German case control population of }\end{array}$ & Review of GWAS on adiposity & Speakman et al. 2013 [112] \\
\hline $\begin{array}{l}\text { Extracellular matrix } \\
\text { disassembly }\end{array}$ & $\begin{array}{c}\text { SH3PXD2B (SH3 and PX } \\
\text { domain-containing protein 2B) }\end{array}$ & $\begin{array}{l}487 \text { extremely obese children and adolescents } \\
\text { and } 442 \text { healthy lean individuals; and an } \\
\text { adult population of } 1644 \text { individuals from the } \\
\text { German population-based study (KORA) }\end{array}$ & Candidate gene approach on obesity & Vogel et al. 2009 [113] \\
\hline $\begin{array}{l}\text { Extracellular matrix } \\
\text { organization }\end{array}$ & $\begin{array}{l}\text { SLC2A10 (Solute carrier family 2, facilitated } \\
\text { glucose transporter member 10) }\end{array}$ & $\begin{array}{c}56,000 \text { unrelated individuals of several } \\
\text { ethnics and cohorts }\end{array}$ & GWAS on adiposity & Hoggart et al. 2014 [114] \\
\hline
\end{tabular}

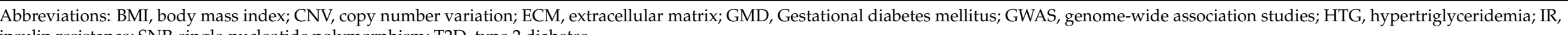
insulin resistance; SNP, single-nucleotide polymorphism; T2D, type 2 diabetes. 
From this search, 80 entries at the locus level were collected, corresponding to 67 unique scientific articles. After removing all entries not asserting our inclusion criteria, 61 entries finally remained (corresponding to 52 scientific articles). These entries mapped 15 gene ontology terms that were merged into broader biological categories according to expert knowledge: (I) Collagen-containing ECM, (II) Cell adhesion, (III) Endothelial cell migration, and (IV) ECM assembly and disassembly. These 4 biological categories refer to structures and processes of great importance in ECM with a direct connection to adipose tissue dysfunction, and lastly to insulin resistance. Bellow, results in Table 1 are summarized according to each of these categories.

The collagen-containing extracellular matrix category comprise a range of proteins (especially collagens and glycosaminoglycans, mostly as proteoglycans) that provide not only essential physical scaffolding for the cellular constituents but can also initiate crucial biochemical and biomechanical cues required for tissue morphogenesis, differentiation and homeostasis. These proteins are the main ECM component in adipose tissue and their excessive accumulation in obesity is the main cause of tissue fibrosis, rigidity, and finally insulin resistance. A total of 12 GWAS-reported loci were grouped into this category after the search (ADIPOQ, APOE, CBLN4, COL4A1, COL6A5, CTSS, F12, F13A1, FRAS1, ITIH4, $S G C Z$, and $S S P N)$ [64-66,69-71,73,78-80,84-87,89,92-96]. From these, it highlights structural collagen components such as COL4A1, COL6A5 and other types of structural ECM components such as FRAS1, SGCZ, and SSPN, for which SNPs and CNVs have been directly associated with higher risk of obesity or increased anthropometry measurements in diverse ethnic populations (at genome-wide significance levels $\mathrm{P}<5 \times 10^{\mathrm{e}-8}$ ) $[62,67,68,72,74,75]$. Furthermore, it is also remarkable the association of the gene cathepsin S (CTSS), known to degrade several components of the ECM, which is produced by human adipocytes and increased in obesity. A novel SNP within this gene, the rs2230061, was associated with Fat Body Mass after the adjustment of lean body mass $\left(\mathrm{P}=3.57 \times 10^{\mathrm{e}-8}\right)$ at the genome-wide significance level.

The cell adhesion category comprised any process by which cells form contacts with each other or with ECM components through different receptors. Particularly, this category included loci mapping GO terms such as adherens junctions, cell adhesions involved in heart morphogenesis, cell adhesion molecule binding, cell-matrix adhesions, focal adhesions, and regulation of cell adhesions. Among others, this section included GWAS-reported associations mapping proteins such as Cadherins; a group of transmembrane glycoproteins that mediate intercellular adhesion in the presence of extracellular calcium and play important roles in cell-cell adhesions. Likewise, there were also matrix metalloproteinases (such as ADAMs), with disintegrin-binding regions, that can interact with integrins and mediate cell-ECM interactions. As it can be seen in Table 1, a total of 21 GWAS-reported loci were gathered in the category (ADAM23, ADAMTS9, BCL6, C2CD4A, CD36, CDH12, CDH18, CELSR2, COBLL1, CSK, FLRT2, IDH1, IGF1, IGF1R, INSR, LEP, NRXN3, OLFM4, PFKP, RREB1, and TCF7L2). Among them, we differentiate between loci exclusively associated with obesity and others, which also presents associations with insulin resistance or T2D (Table 1). For the loci annotated in the GO term adherens junctions, it outstands the locus TCF7L2, which is a transcription factor acting downstream of B-catenin and involved in blood glucose homeostasis. Interestingly, TCF7L2 is one of the top loci associated with increased T2D risk in a wide range of studies [90]. Within the adherens junctions GO term, it is also interesting the association reported for the insulin receptor gene INSR, for which SNPs have been identified as functional variants affecting gene expression directly or indirectly via epigenetic (CpG-methylation) alterations [90]. Among the 21 GWAS-reported loci that were annotated into this category, we also reported two genes strongly related to each other (IGF1, IGF1R). SNPs within these genes have been associated both with weight-loss variability (in response to bariatric surgery intervention) and with higher indexes of IR in non-diabetic subjects [88]. This is interesting, since both loci mediate the production of adhesion molecules by endothelial cells and monocyte adhesion onto the vascular endothelium in response to the hyperinsulinemic state. Therefore, they probably exert a 
strong contribution to the pathogenesis of atherosclerotic disease in diabetes and obesity. In relation to matrix metalloproteinases, it outstands the ADAM23, ADAMTS9, for which SNPs have been associated with increased BMI and metabolic alterations (mainly lipid and glucose traits), respectively [75-77]. Finally, we also reported GWAS-associations within cadherin-type proteins such as (CDH12, CDH18, and CELSR2), associated with obesity and CRP serum levels, respectively [81-83].

In the Endothelial Cell migration category, we gathered all GWAS loci regulating the orderly movement of endothelial cells into the ECM to form an endothelium. Particularly, increased angiogenesis is a consequence of insulin resistance in adipose tissue. As a result, this category included a total of 6 GWAS-reported loci (MAP2K3, MAP2K5, MET, PPARG, PROX1, and SIRT1). Among them, it highlights (MAP2K5 and PPARG) with a negative effect on the endothelial cell migration, for which SNPs have been repeatedly associated with obesity in several populations (especially in Asians) $[63,91,99-104,106,107]$. The rest of these loci were involved in a positive regulation of the endothelial cell migration, and their SNPs have been associated not only with an increased risk of obesity but also with T2D or gestational diabetes mellitus [97,98,105,108-110].

Finally, in the ECM assembly and disassembly category, we grouped all GWAS-reported loci involved in any process that results in the assembly, arrangement of constituent parts, or disassembly of the ECM. These processes are of special importance in obesity and metabolic dysfunction given the described mechanisms associated with disturbed ECM remodeling in adipose tissue expansion. A total of 5 GWAS loci (GP2, IL6, LINGO2, $S H 3 P X D 2 B$, and SLC2A10) were gathered into this category. From these, all showed strong associations with obesity (at genome-wide significance level or validated in independent samples) [104,111,112,114], except the SH3PXD2B, for which no evidence was found in two GWA samples [113].

\section{Whole-Genome DNA Methylation Approaches Reveal the Implication of ECM in Obesity and Metabolic Dysfunction}

In this section, we assembled all literature findings from EWAS experiments revealing the implication of ECM in obesity and metabolic dysfunction. We collected and organized according to ECM gene ontology terms, specifically focusing on biological process terms, but associations do not mean causative process (Table 2). In this search we initially collected 47 scientific articles, and after removing all entries not asserting our inclusion criteria, 23 finally remained. Different cell signaling pathway categories sorted these articles: collagens; cell adhesion; endothelial cell migration; regulation of cytoskeleton; and ECM assembly and disassembly. These categories refer to processes and cell-matrix interactions in ECM, which have been associated with metabolic dysfunction in the adipocytes, and lastly in the whole adipose tissue and SM. Bellow, results from Table 2 are summarized according to each of these categories. 
Table 2. DNA methylation approaches reveal the implication of ECM in obesity and metabolic dysfunction.

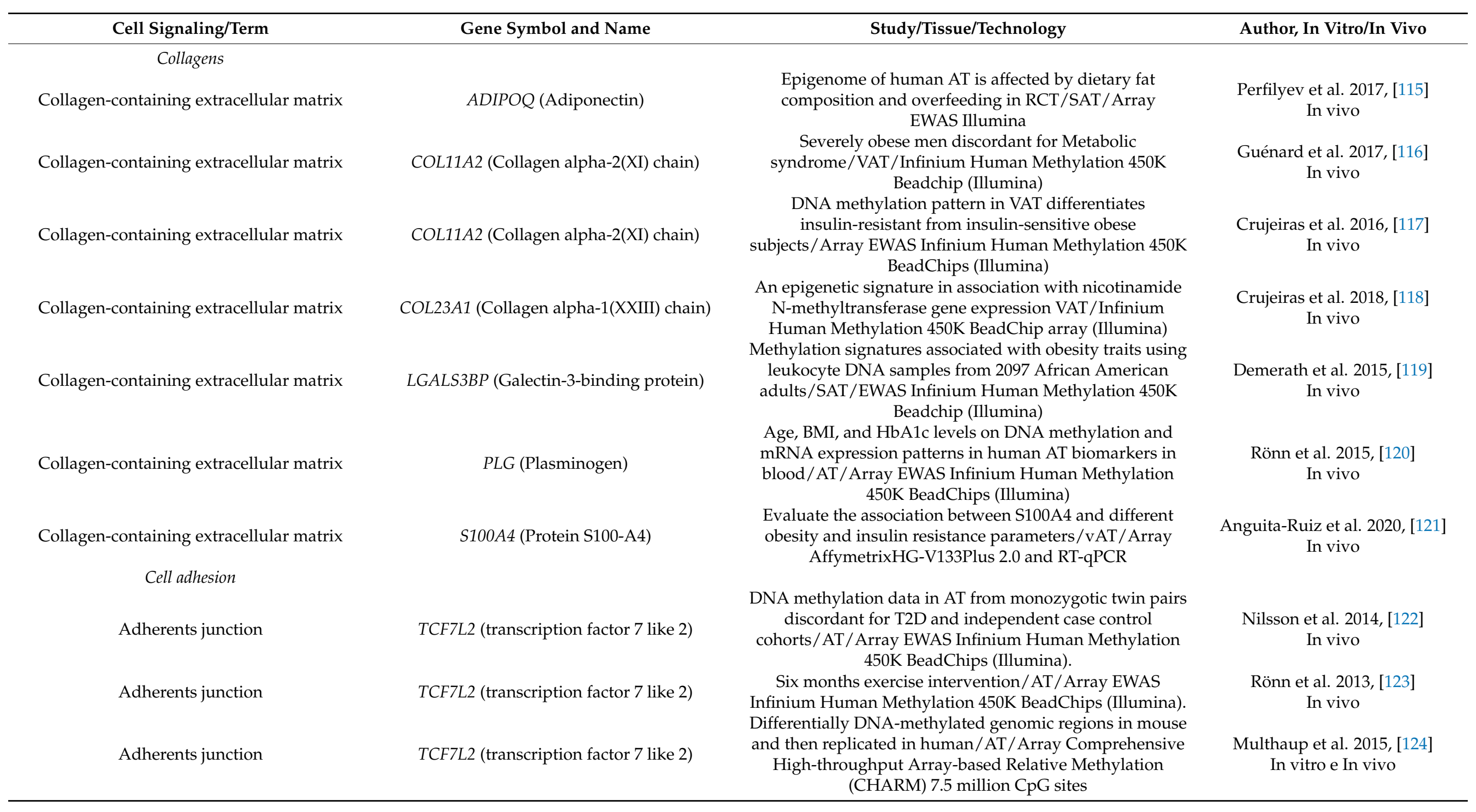


Table 2. Cont.

\section{Cell Signaling/Term}

Cell adhesion molecule binding

Cell adhesion molecule binding

Cell adhesion molecule binding

Cell adhesion molecule binding

Cell adhesion molecule binding

Cell matrix adhesion

Cell matrix adhesion

Cell matrix adhesion

Cell matrix adhesion

Cell matrix adhesion
Gene Symbol and Name

SPP1 (Osteopontin)

SPP1 (Osteopontin)

BAG3 (BAG family molecular chaperone regulator 3)

COL5A1 (Collagen alpha-1(V) chain)

ADAM2 (Disintegrin and metalloproteinase domain-containing protein 2)

CD36 (Platelet glycoprotein 4)

CD36 (Platelet glycoprotein 4)

SFRP1 (Secreted frizzled-related protein 1)

CDK5 (Cyclin-dependent-like kinase 5)

CD44 (CD44 antigen)

Study/Tissue/Technology

DNA methylation data in AT from monozygotic twin pairs discordant for T2D and independent case control cohorts / AT / Array EWAS Infinium Human Methylation 450K BeadChips (Illumina)

Age, BMI, and HbA1c levels on DNA methylation and mRNA expression patterns in human AT biomarkers in blood/AT/Array EWAS Infinium Human Methylation 450K BeadChips (Illumina)

Gene expression and DNA methylation respond to both short- and long-term weight loss/SAT/Infinium

$$
\text { HumanMethylation 450K BeadChip }
$$

The epigenetic signature of systemic insulin resistance in obese women/SAT and VAT/Array EWAS Infinium

Human Methylation 450K BeadChips (Illumina).

Genome-wide DNA methylation pattern differentiates insulin-resistant from insulin-sensitive obese subjects/VAT / Array EWAS Infinium Human Methylation 450K BeadChips (Illumina).

Case control study in 2 independent cohorts of obese/non-obese individuals/SAT and VAT/EZ DNA Methylation kit (Zymo)

Case control study in obese subjects (Obese+Obese T2D) to evaluate if extracellular factors in obesity epigenetically reprogram adipogenesis potential and metabolic function of preadipocytes/VAT/Array EWAS RRBS

Role of a DNA methyltransferase (Dnmt3a) in obese AT

from transgenic mice overexpressing Dnmt3a/AT/Array GWAS Affimetrics Mouse Genome 4302.0

Case control study/SAT / Affymetrix Human Gene 1.0 ST arrays and DNA methylation using Illumina $450 \mathrm{~K}$ BeadChip arrays.

Genome-wide DNA methylation pattern in insulin-resistant from insulin-sensitive obese subjects/VAT/Array EWAS Infinium Human Methylation 450K BeadChips (Illumina).
Author, In Vitro/In Vivo

Nilsson et al. 2014, [122]

In vivo

Rönn et al. 2015, [120]

In vivo

Bollepalli et al. 2018, [125] In vivo

Arner et al. 2016, [126]

In vivo

Crujeiras et al. 2016, [117]

Keller et al. 2017, [127]

In vivo/In silico

Andersen et al. 2019, [128]

In vivo

Kamei et al. 2010, [129]

In vivo/In vitro

Gillberg et al. 2016, [130]

In vivo

Crujeiras et al. 2016, [117] In vivo 
Table 2. Cont.

\section{Cell Signaling/Term}

Regulation of cell adhesion

Regulation of cell adhesion

Regulation of cell adhesion

Regulation of cell adhesion

Tight junction

Focal adhesion

Focal adhesion

ECM assembly and disassembly

Extracellular matrix

Extracellular matrix assembly
Gene Symbol and Name

\section{HLA-DPB1 (HLA class II histocompatibility} antigen, DP beta 1 chain)

MAPK7 (Mitogen-activated protein kinase 7)

IGFBP2 (Insulin-like growth factor-binding protein 2)

CCL2 (C-C motif chemokine 2)

CLDN1 (claudin 1)

AKT2 (AKT serine/threonine kinase 2)

\section{PHOSPH + B33O1}

(Phosphoethanolamine/phosphocholine phosphatase)

NOTCH1 (Neurogenic locus notch homolog protein 1)

Study/Tissue/Technology

Age, BMI and HbA1c levels on DNA methylation and mRNA expression patterns in human AT biomarkers in blood/AT/Array EWAS Infinium Human Methylation 450K BeadChips (Illumina)

A RCT to study if the epigenome of human AT is affected differently by dietary fat composition/SAT / Array (Infinium Human Methylation 450K BeadChip, Illumina) Epigenetic changes of the IGFBP2 gene associated with obesity by DNA methylation and mRNA expression in adipocytes from different depots/SAT and VAT/Array

$$
\text { (Bisulfite pyrosequencing, PyroMark Q96) }
$$

Adipocyte-expressed 1CC genes linked to WAT

inflammation and IR from obese individuals/SAT, isolated adipocytes and in vitro adipocytes / Array (GeneChip ${ }^{\circledR}$

Human Transcriptome Array 2.0 (Affymetrix) and EZ DNA Methylation-Gold Kit

Genome-wide DNA promoter methylation along with mRNA profiles in non-obese vs. obese individuals/SAT and VAT/Array (Infinium HumanMethylation450K BeadChips (Illumina)

Case control study in subjects subdivided according BMI aimed to identify AT dysfunction involved in decreasing insulin action in adipocytes/SAT / Array EWAS (Illumina HumanMethylation27 BeadChip) + TWAS (Affymetrix Human 1.0 or $1.1 \mathrm{ST}$ arrays) + pyrosequencing + RT-PCR

DNA methylation loci in blood DNA (ABCG1, PHOSPHO1, SOCS3, SREBF1, and TXNIP) as predictors of future

T2D/AT, blood, human pancreatic islets, liver, and skeletal muscle/Array EWAS Illumina Infinium Human Methylation 450K Beadchip

Smoking-associated DNA methylation and gene expression variation in AT biopsies from 542 healthy female twins/SAT, blood/Array EWAS Illumina Infinium Human Methylation 450K Beadchip

\section{Author, In Vitro/In Vivo}

Rönn et al. 2015, [120] In vivo

Perfilyev et al. 2017, [115] In vivo

Zhang et al. 2019, [131] In vivo

Petrus et al. 2018, [132] In vivo/In vitro

Keller et al. 2017, [127]

In vivo

Rydén et al. 2019, [133] In vivo

Dayeh et al. 2016, [134] In vivo

Tsai et al. 2018, [135] In vivo 
Table 2. Cont.

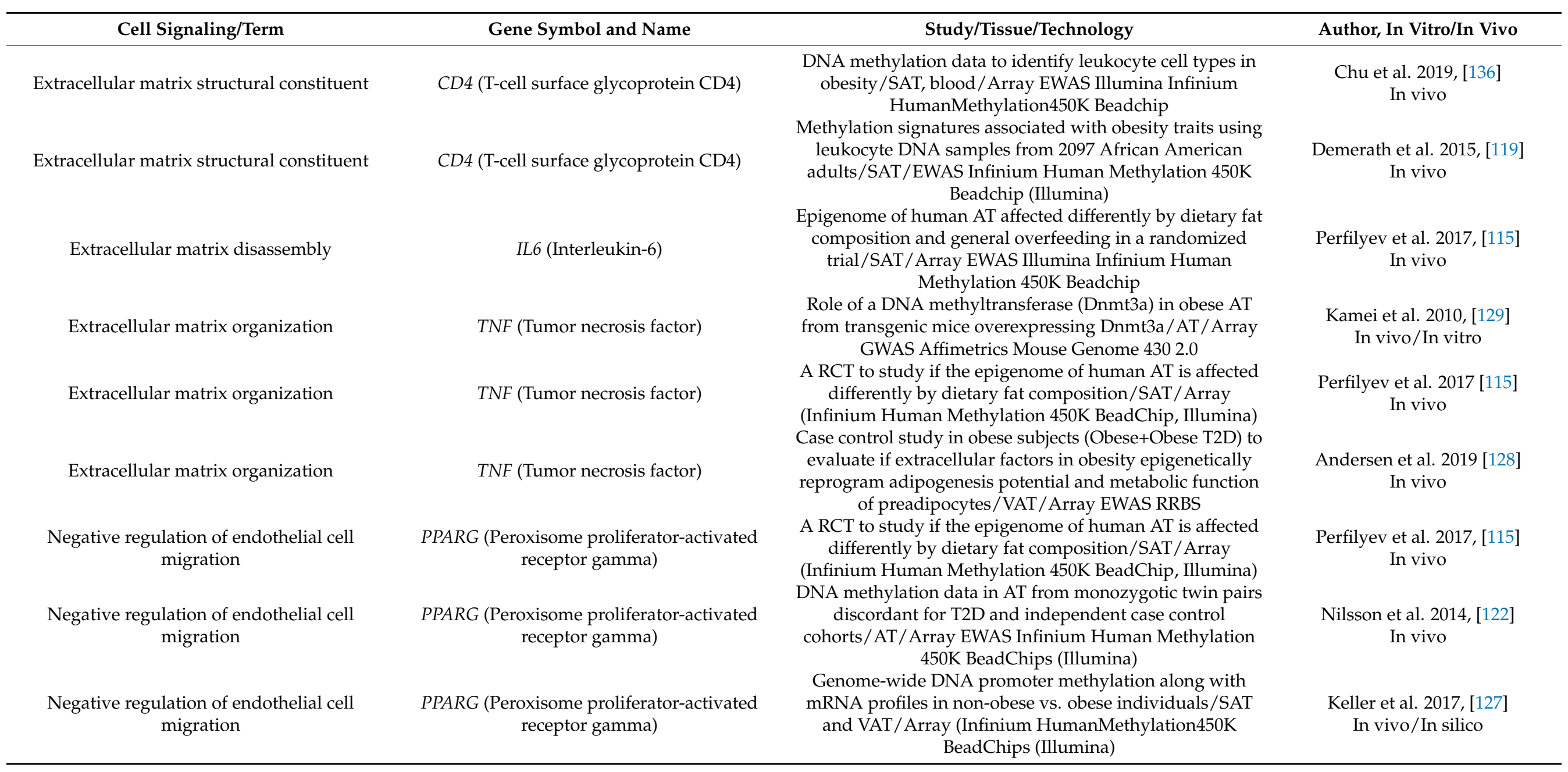


Table 2. Cont.

\section{Cell Signaling/Term}

Regulation of cytoskeleton

Regulation of actin cytoskeleton

Regulation of actin cytoskeleton
Gene expression and methylation data from diabetic and healthy individuals/VAT/Array EZ-DNA methylation kit and Illumina Human Methylation 450K BeadChip

Association of CPG-SNPs located within ARPC3, which is linked to adipogenesis/VAT / Array High-throughput array technology QuantStudio 12K Flex System
Wang et al. 2018, [65]

In vivo

Toro-Martín et al. 2016, [137] In vivo

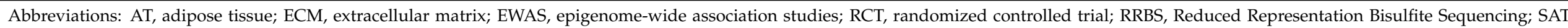
subcutaneous adipose tissue; SNP, single-nucleotide polymorphism; T2D, type 2 diabetes; VAT, visceral adipose tissue. 
The collagen-containing ECM category included 6 EWAS-reported genes derived from our search (ADIPOQ, COL11A2, COL23A1, LGALS3BP, PLG, and S100A4). Although collagens are the main ECM proteins in adipose tissue, the methylation of some other genes in adipose tissue might also present some impact in fibrosis, stiffness, and adipocyte dysfunction, and ultimately in insulin resistance. In the case of the adipokine $A D I P O Q$ (Adiponectin, C1Q, and Collagen domain containing), which it is secreted by adipocytes regulating insulin sensitivity, Perfilyev et al. (2017) showed that its mean methylation was increased in SAT after saturated fatty acid (SFA) overfeeding, and that it may contribute to the decreased adiponectin concentrations commonly observed in obese individuals [115]. Fibrosis, tissue inflammation, and insulin resistance are linked in adipose tissue, however, the causality direction of such relationship seems to be unclear [138]. On this matter, a recent study has reported that insulin resistance promotes accumulation of M1 macrophages and fosters inflammation [139]. In obese WAT, both hypoxia and inflammation induce a pathological expansion of ECM with macrophages recruitment and increased collagens deposition. Interestingly, epigenetic mechanisms could participate in this regulation of adipose tissue morphology associated with ECM remodeling. In the case of COL11A2, two different studies have evaluated the contribution of methylation levels in VAT either in obese individuals with metabolic syndrome or in individuals with insulin resistance. From these, Guenard et al. (2017) identified a higher degree of methylation for 2 COL11A2 CpGs in the VAT of obese men with metabolic syndrome. Interestingly, these $2 \mathrm{CpGs}$ were reported to interact with SNPs and affect fasting plasma glucose levels, providing a potential biological mechanistic insight on the development of metabolic syndrome [116]. Likewise, COL11A2 exhibited higher methylation levels in the VAT of individuals with insulin resistance compared to normal insulin sensitivity controls [117]. Similarly, COL23A1 showed lower methylation levels in morbidly obese patients, and these levels were associated with the activity of the enzyme nicotinamide N-methyltransferase, which is a major methyltransferase associated with BMI and insulin resistance. Those results were confirmed in two different cohorts and validated in a weight loss intervention study, linking low methylation levels of COL23A1 with adipose tissue dysfunction [118]. Within this collagens category, it also outstands the lectin galactoside-binding soluble 3 binding protein (LGALS3BP), a macrophage inflammatory marker, for which a higher methylation in SAT was associated with adiposity [119]. On the other hand, Roon et al. (2015) found that plasminogen $(P L G)$ was differentially methylated in human SAT from subjects with T2D compared to non-diabetic controls, and its methylation levels were negatively correlated with age and expression [120]. Within this category, it is also important to highlight the S100A4 metastasis-associated protein, for which our research group have reported an association with insulin resistance and WAT dysfunction in prepubertal populations. Interestingly, we reported how the change in plasma S100A4 levels accompanies longitudinal trajectories of insulin resistance in children and how the methylation levels for two-enhancer-related CpG sites of the S100A4 region (cg07245635 and cg10447638) perfectly correlate with insulin resistance biomarkers at the prepubertal stage [121].

Secondly, within the cell adhesion category, we included GO terms such as adherens junctions, cell adhesion molecule binding, cell matrix adhesion, regulation of cell adhesion, and tight junctions. As can be seen in Table 2, a total of 15 EWAS-reported genes were gathered in this category (ADAM2, BAG3, CCL2, CD36, CD44, CDK5, CLDN1, COL5A1, HLA-DPB1, IGFBP2, $L E P, M A P K 7, S F R P 1, S P P 1$, and TCF7L2). Annotated with the GO term adherens junction, TCF7L2 is one of the most important loci in the category. Interestingly, TCF7L2 is also a GWAS-reported locus associated with T2D and glucose homeostasis. Here, we found that differential DNA methylation in TCF7L2 is also associated with obesity and TD2 according to three different studies. Particularly, it has been described that the methylation of TCF7L2 is lower in SAT from monozygotic twin pair's unrelated subjects with T2D compared to control subjects [122]. Similarly, lower DNA methylation of TCF7L2 in SAT was associated with BMI [123]; and associated with insulin resistance in adipose tissue samples from lean and obese patients pre- and post-Roux-en-Y gastric bypass. In this study, TCF7L2 
genetic variation was highlighted as a cause for the changes in methylation and with a direct implication in the development of T2D [124]. Mapping the Go term cell adhesion molecule binding, we find the SPP1, which encodes the inflammatory cytokine osteopontin. This locus was found to be more methylated in human SAT from subjects with T2D in comparison to non-diabetic controls, and this methylation has previously been linked to a higher expression level in adipose tissue and inflammation [120]. In concordance with these results, Nilsson et al. (2014) showed a different DNA methylation pattern of SPP1 between the SAT of monozygotic twin pairs unrelated subjects with T2D and control subjects [122], supporting the biological validation of described genetic-epigenetic modifications of SPP1 in adipose tissue. Another study showed that BAG3, an anti-apoptotic protein and an indicator of cellular stress, is differentially methylated after short- and long-term weight loss programs in SAT of healthy participants, resulting in a downregulation of gene expression and demonstrating a response during weight loss; however, no changes were found in VAT [125]. Another study showed higher DNA methylation of COL5A1 in the VAT of women with insulin resistance, revealing an epigenetic regulation of COL5A1 and its implication in pathways related to integrin cell interactions and insulin signaling in VAT [126]. In this sense, $A D A M 2$, a type of disintegrin regulating cell-matrix interactions, exhibited lower methylation in VAT of insulin resistance subjects than in healthy individuals, revealing a potential epigenetic regulation of adipose tissue dysfunction [117]. In the cell matrix adhesion GO term, we identified four genes (CD36, SFRP1, CDK5, and CD44). From them, the fatty acid translocase $C D 36$, which is involved in lipid metabolism, was more methylated and less expressed in VAT among non-obese subjects and affects metabolism through several mechanisms [122]. Moreover, Andersen et al. (2019) reported that preadipocytes of VAT from obese and T2D subjects are transcriptionally different in response to differentiation in culture, compared to those of lean, showing impaired insulin signaling and a further transcriptomic shift towards altered adipocyte function. Thus, cultures with a lower expression magnitude of adipogenic genes throughout differentiation such as $C D 36$ were associated with DNA methylation at remodeling in genes controlling insulin sensitivity and adipocytokine signaling pathways, supporting the role of $C D 36$ in adipocyte function [128]. SFRP1 is a modulator of Wnt/ $\beta$-catenin signaling regulating adipogenesis, and its expression is reduced in obesity [140]. Epigenetic modifications of SFRP1 were reported in mice overexpressing DNA methyltransferase enzyme in the adipose tissue, showing how a slight increase in the methylation of SFRP1 associates with a marginal suppression of its gene expression and higher inflammatory markers, therefore linking epigenetic changes to inflammation in adipose tissue [129]. CDK5, which phosphorylate PPAR $\gamma$ in adipocytes, is highly methylated in SAT after five days of high-fat overfeeding in individuals who had low birthweight, indicating how short-term overfeeding influences methylation and gene transcription in adipose tissue [130]. The cell-surface glycoprotein CD44, involved in cell-cell interactions, exhibited higher methylation in VAT of insulin resistance than in healthy individuals, demonstrating that VAT from patients with disturbances in the insulin sensitivity presents a specific DNA methylation pattern [117]. In the GO term regulation of cell adhesion, the loci HLA-DPB1, LEP, MAPK7, IGFBP2, and CCL2 were gathered. HLA-DPB1, which plays an essential role in obesity-induced adipose inflammation, is hypermethylated in human SAT and positively correlated with $\mathrm{HbA1c}$, supporting the link between inflammation and systemic insulin resistance [120]. The MAPK7, which plays a pivotal role in proliferation and differentiation, is hypermethylated in SAT in response to SFAs compared to polyunsaturated fatty acids (PUFAs) intake, supporting that SFA overfeeding induces distinct epigenetic changes in human SAT and this might affect to ECM remodeling in the tissue [115]. IGFBP2 is the second most circulating IGFBP secreted by liver and white adipocytes, and DNA methylation levels are higher in VAT, also SAT but lower compared to VAT, from subject with obesity, indicating a potential implication of IGFBP2 in abdominal obesity [131]. We continuously show here that DNA methylation in ECM-associated genes influences inflammation in adipose tissue. Thus, Petrus et al. (2018) demonstrated that adipocytes of SAT from obese individuals' exhibit a global 
DNA hypermethylation associated positively with gene expression of proinflammatory pathways. Besides, they observed that SLC19A1 knockdown, a folate carrier, induced DNA hypermethylation of CCL2 in the promoter-located cg12698626 in human adipocytes, further resulting in a higher inflammation in WAT and adipocyte dysfunction, finally contributing to the development of insulin resistance [132]. Within the GO term tight junction, claudin 1 (CLDN1), encoding an integral membrane protein and a component of tight junction strands, was strongly hypermethylated in human VAT and SAT of obese subjects compared to normal weight. In addition, CLDN1 expression is lower in SAT compared to VAT from non-obese individuals, suggesting a functional role of CLDN1 in VAT [127]. In relation to the focal adhesion GO term, one interesting study reported that adipocytes from overweight/obese people display decreased insulin sensitivity and reduced expression of $A K T 2$, which it is associated with higher methylation at regulatory sites in the AKT2 promoter. These findings indicate that healthy and non-diabetic subjects have already disturbed insulin signaling in the overweight state; it is worsened in healthy obese individuals and being only slightly aggravated in metabolically unhealthy obesity, consequently contributing to early defects in insulin action in adipocytes [133].

In the endothelial cell migration category, PPARG was hypermethylated in SAT [115,122], and VAT [127], and it was associated with obesity, indicating an important role of this gene in the reorganization of ECM.

The regulation of cytoskeleton category included 3 EWAS-reported genes that were collected after the search (ARHGEF1, ARHGEF4, and ARPC3). Many of the cytoskeletal proteins found within the cell interact with extracellular matrix proteins, and linkage between cell surface receptors responsible for sensing the matrix and the cytoskeleton may be relevant to understanding the mechanism behind those responses. Actin-related protein $2 / 3$ complex subunit 3 (ARPC3) is a gene recently linked to adipogenesis and lipid accumulation in obese people. A significant association was found between the CpG-SNP rs3759384 (C > T) and plasma triglyceride (TG) levels. In addition, the carriers of the rs3759384 T allele also showed a significant decrease in methylation levels of the ARPC3 promoter-associated CpG site cg10738648 in VAT. Therefore, ARPC3, which is involved in cytoskeleton organization during adipose tissue expansion, might have an impact on the development of metabolic syndrome, acting through the regulation of DNA methylation in VAT [137]. Wang et al. (2018) described that the rho guanine nucleotide exchange factor 1 (ARHGEF1) gene is hypermethylated in VAT from diabetic individuals compared with healthy controls. So far, those genes could be diabetes susceptibility genes epigenetically regulated in VAT [141].

Finally, in the ECM assembly and disassembly category, we collected all EWAS-reported loci involved in any process that results in the assembly, arrangement of constituent parts, or disassembly of the ECM. In this category, 5 EWAS-reported genes were collected (PHOSPHO1, NOTCH1, CD4, IL6, and TNF). Dayeh et al. (2016) identified that DNA methylation at the PHOSPHO1 locus (cg02650017) in blood DNA is associated with a decreased risk for future T2D and positively correlated with HDL levels. Besides, they found a decreased DNA methylation of PHOSPHO1 locus (cg02650017) in SM from diabetic versus nondiabetic monozygotic twins, suggesting a pivotal role of this gene in ECM in SM associated with metabolic disease [134]. Another study investigated the smoking-associated DNA methylation in adipose tissue, and they observed that smoking-associated differentially methylated regions in NOTCH1 were significantly associated with measures of metabolic disease [135]. The CD4 has been found to be differentially methylated in monocytes, and dendritic cells in SAT and negatively associated with android fat mass, confirming that higher leukocyte infiltration is directly associated with higher levels of adiposity. Consequently, epigenetic signatures could potentially be used as biomarkers for identifying leukocyte infiltration and risk of insulin resistance [136]. Likewise, Demerath et al. (2015) also reported higher DNA methylation in the CD4 gene in SAT [119]. In the Perfilyev et al. (2017) study, they also found higher DNA methylation in SAT of IL6 associated with the degree of weight increase in response PUFA overfeeding [115]. 
Overall, omics approaches have been robustly used to understand the implication of DNA methylation and its consequences at in the ECM remodeling in adipose tissue expansion, in relation to different cell signaling such as cell adhesion, collagens, and ECM assembly that can contribute to adipocyte dysfunction, and therefore, in the whole-body metabolism in obesity.

\section{Whole-Genome Gene Expression Approaches Reveal the Implication of ECM in Obesity and Metabolic Dysfunction}

Gene expression levels reflect the combined effect of a wide range of genomic modifications including point mutations, structural variants, and epigenetic changes. Furthermore, some specific mRNA is likely more closely reflecting the overall genomic effects than each type of variation separately [142]. In this context, gene expression patterns in adipose tissue and SM are used to study various aspects of systemic metabolism. Here, we will summarize the differential gene expression, by using microarrays or RNA-seq approaches, revealing the implication of the ECM in adipose tissue and SM in obesity and metabolic complications. Findings related to gene expression were also organized according to ECM gene ontology terms (Table 3). Terms are merged according to expert knowledge: collagens, cell and focal adhesion, endothelial cell migration, and ECM assembly and disassembly. 
Table 3. Integrative analysis of gene expression patterns revealing ECM implication in obesity and metabolic dysfunction.

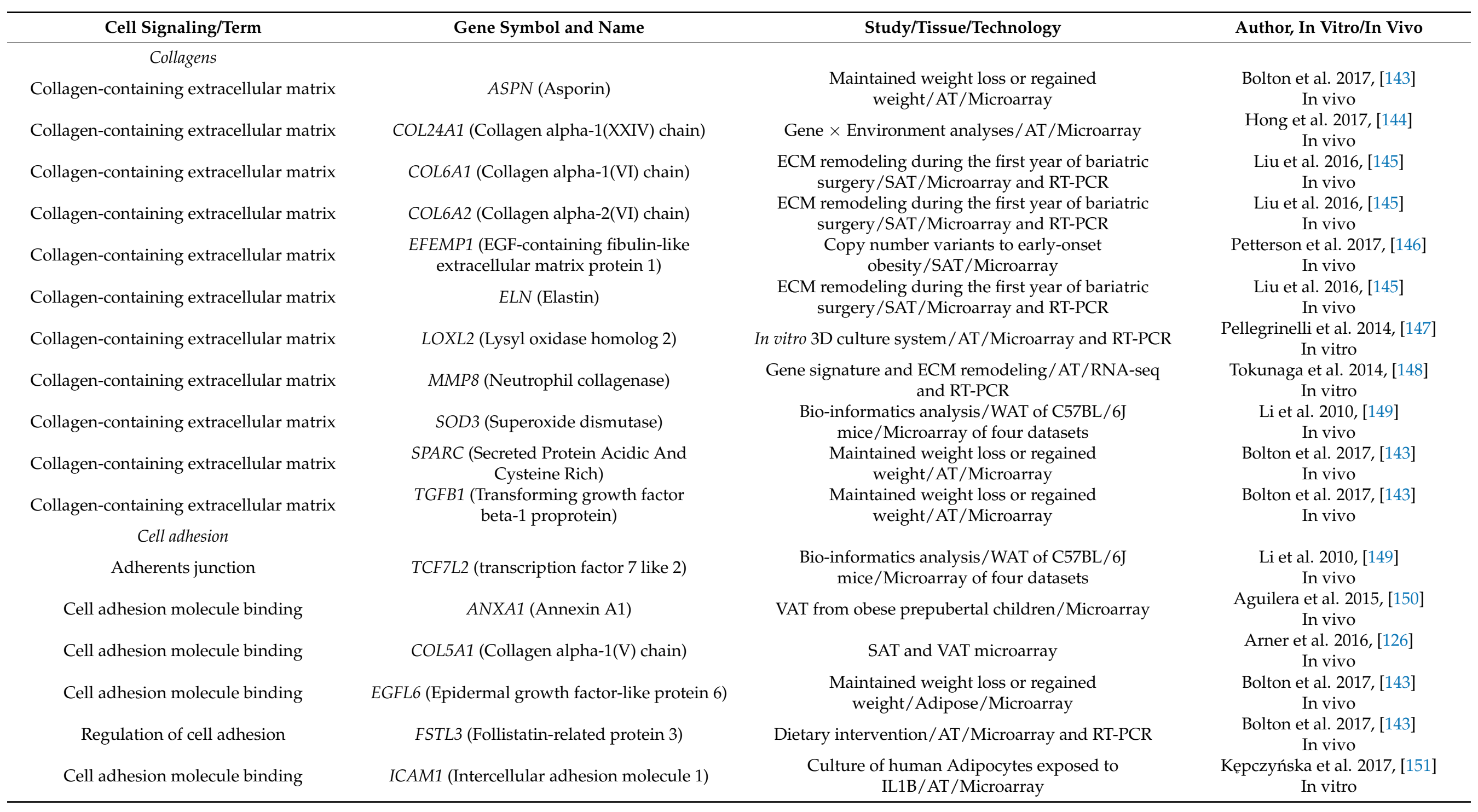


Table 3. Cont.

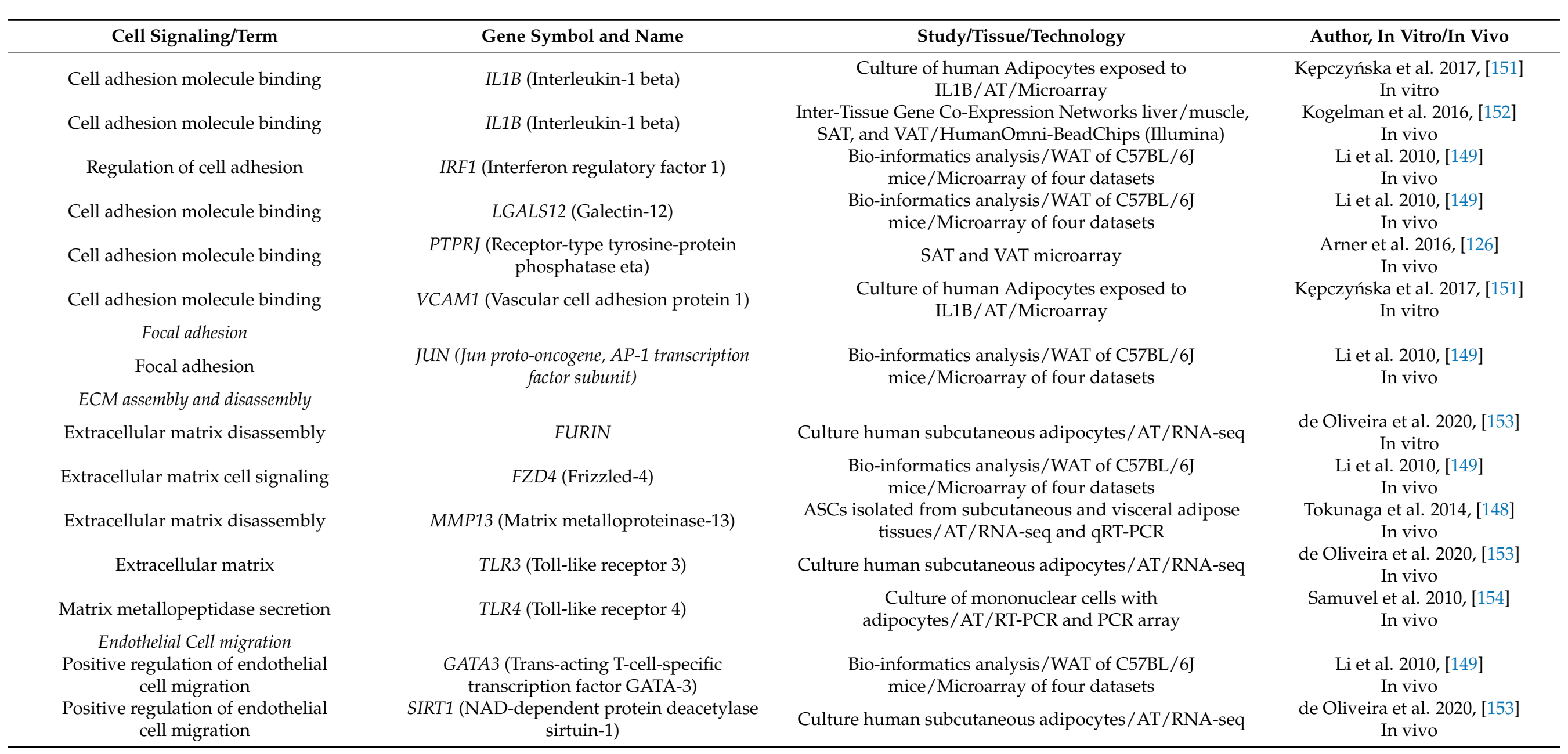

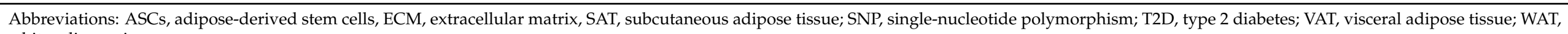
white adipose tissue. 
In the collagen-containing ECM category are included 11 genes (ASPN, COL24A1, COL6A1, COL6A2, EFEMP1, ELN, LOXL2, MMP8, SOD3, SPARC, and TGFB1). As abovementioned, collagens accumulation contributes to fibrosis in adipose tissue upon weight gain, however, the evolution of ECM remodeling in SAT after weight loss was not entirely understood. ASNP is highly expressed in adipocytes and it is associated with ECM, and higher baseline expression in SAT in individuals who successfully maintained weight loss was relevant for prevention of weight (re)gain. Interestingly, ASPN is a TGFB1 inhibitor and the increased inhibition of TGFB1 pathway by ASPN resulted in increased weight control. However, the ECM glycoprotein SPARC exhibited lower expression in individuals who had the greatest decreases in BMI. Those genes emphasize the potential role of tissue fibrosis in long-term weight control [143]. Another study has identified that maternal COL24A1 variants, in particular, rs11161721 is the top one showing a significant genome-wide interaction with maternal pre-pregnancy overweight and obesity on preterm birth risk. Interestingly, in adipose tissue, the variant rs11161721 is significantly associated with altered COL24A1 expression, providing new insights about a novel gene-maternal pre-pregnancy BMI interaction on preterm birth [144]. Some genes are also affected by rare CNVs in subjects with obesity, and thereby, this drives an alteration in gene expression of epidermal growth factor EFEMP1, which is involved in ECM remodeling in SAT, indicating that rare CNVs could be involved in the development of early-onset obesity [146]. Concerning bariatric surgery and weight control, a study conducted transcriptomic and histological characterization in SAT after the first year of bariatric surgery and, interestingly, they found higher degraded collagen accumulation in SAT after bariatric surgery along with fat mass loss and different gene expression of ECM components such as COL3A1, COL6A1, COL6A2, and ELN. Therefore, adipose tissue is able to adapt after a drastic weight loss, showing an increase in collagen degradation, but further studies are needed in order to follow up patients during long-term weight loss and elucidate the impact of adipose tissue remodeling in the systemic metabolism [145]. In relation to adipogenesis, by using an in vitro 3D culture system, Pellegrinelli et al. (2014) described in human adipocytes and decellularized material of adipose tissue (dMAT) from obese individuals a higher inflammatory and fibrotic gene expression of LOXL2, suggesting that fibrosis affects negatively to human adipocyte function via mechanosensitive molecules [147]. Li et al. (2010) identified that Sod3, concerned with oxidative stress, co-varies with the neuronatin (Nnat) promoter in mice adipocytes, which is an acute diet-responsive gene in adipose tissue affecting adipogenesis and metabolism [149].

Here, the cell adhesion category included 12 genes (ANXA1, COL5A1, EGFL6, FSTL3, ICAM1, IL1B, IRF1, JUN, LGALS12, PTPRJ, TCF7L2, and VCAM1). In this category, the GO terms adherents junctions, cell adhesion molecule binding, and regulation of cell adhesion are included (Table 3). Regarding inflammation and the term cell adhesion molecule binding, our research team showed that ANXA1, which is involved in the inflammatory process, is upregulated in the VAT of obese compared to normal weight prepubertal children [150]. In a different study from Arner et al. (2016), as it is described in the methylation section, 51 genes were reported as differentially expressed in VAT of insulin resistance obese women (e.g., COL5A1 and PTPRJ), revealing the different gene expression patterns in adipose tissue [126]. IL-1 $\beta$, a leukocytic pyrogen activated by macrophages, is involved in the inflammatory process, and its expression in the regulation of ECM and cell adhesion has been examined in human adipocytes. The incubation with IL-1 $\beta$ in adipocytes upregulates ICAM1 and VCAM1, indicating an effect on the expression of ECM and cell adhesion genes in human adipocytes, consistent with the derangement of tissue structure during inflammation in adipose tissue [151]. A whole-genome expression profile of liver, SM, SAT, and VAT was carried out in metabolically healthy obese and metabolically unhealthy individuals by using the weighted gene co-expression network analysis (WGCNA) to build withinand inter-tissue gene networks. In line with other studies, IL-1 $\beta$ was co-expressed with other genes of insulin-related pathways across tissues in metabolically unhealthy obese compared to metabolically healthy obese people, indicating a potential role in obesity [152]. 
Concerning the GO term adherent junctions, TCF7L2 is one of the top loci associated with increased T2D risk [90]; epigenetic modifications showed by EWAS reporting lower methylation in SAT in T2D individuals [122], and association with BMI [123] and insulin resistance [124]. Therefore, it seems that TCF7L2 in adipose tissue may have an impact on diabetes susceptibility and inflammation. Indeed, higher expression of TCF7L2 was observed in adipose tissue of mice, associated with NNAT expression. Since SNPs in NNAT are found in obese humans, altered NNAT function in adipose tissue indicates an important function in adipocyte metabolism and inflammation [149]. In this study, they also identified that LGALS12 and IRF1 expression, a gene related to adipogenesis, co-varies with NNAT [149]. In relation to body weight, dietary intervention has an effect on weight loss and in gene expression patterns in adipose tissue. An adipose tissue transcriptome identified EGFL6 and FSTL3 differentially expressed in obese individuals who either maintained weight loss or regained weight during a dietary intervention [143].

Focal adhesions are large macromolecular assemblies through which mechanical force and regulatory signals are transmitted between the ECM and interacting cells. Thus, focal adhesion proteins are essential for embryogenic development and/or normal tissue and organ function, thereby elucidation of the mechanism represents a major challenge [155]. In adipose tissue, focal adhesions are implicated in the adipocyte function and insulin action. In particular, focal adhesion kinase (FAK), the central kinase regulating integrin signaling, regulates insulin sensitivity through adipocyte survival, establishing a link between the cell-ECM adhesion processes [156]. In this context, JUN expression, which co-localizes with FAK via a Ras/Rac1/Pak1/MAPK kinase 4 pathway, has been studied in the adipose tissue revealing an implication of JUN in the ECM remodeling in adipose tissue and metabolic function [157].

In the endothelial cell migration category, we gathered all genes regulating the orderly movement of endothelial cells into the ECM to form an endothelium. As a result, this category included SIRT1 and GATA3. SIRT1 expression was downregulated in the human subcutaneous adipocytes after irisin treatment, indicating a putative decrease in the adipocyte function [153]. In the study of Li et al. (2010), they identified GATA3 is highly expressed in adipocytes, associated with NNAT expression, revealing its role in the inflammatory process in adipose tissue [149].

In the ECM assembly and disassembly category, we collected all genes regulating the assembly of ECM components and produced by cells, which are crucial for cellular differentiation, tissue morphogenesis, and physiological remodeling in adipose tissue. As a result, this category included six loci (FURIN, MMP8, MMP13, FZD4, TLR3, and TLR4). A recent study demonstrated that irisin modulates genes associated with severe coronavirus disease 19 (COVID-19) outcomes in human subcutaneous adipocytes. In particular, FURIN regulates angiotensin-converting enzyme 2 (ACE2), which is implicated in the viral infection, and irisin treatment decreases FURIN expression, establishing a link between ECM organization, irisin, and the putative response to viral infection in obesity conditions [153]. FZD4 is a gene involved in adipogenesis and is differentially expressed in adipocytes, and its expression co-varies with NNAT expression [149]. MMP8 and MMP13 expressions are upregulated in adipose-stem cells (ASCs) from VAT compared to ASCs from SAT, suggesting that the fat depot-specific gene signatures of ASCs may contribute to the distinct patterns of ECM remodeling and tissue function in SAT and VAT [148]. Finally, TLR4, a member of toll-like receptor family involved in the inflammatory cytokine production, is increased in the presence of lipopolysaccharide or palmitic acid, and elevated glucose level conditions acts in concert to upregulate osteopontin expression by mononuclear cells through an IL-6-mediated mechanism [154].

ECM of SM is dysregulated in obesity and it is associated with insulin resistance, where collagens are upregulated in SM after 10\% weight gain. Although the evidence of gene expression patterns in muscle is limiting compared to adipose tissue, it is well established a link between SM ECM remodeling and development of metabolic dysfunction [158]. A cohort study in healthy individuals showed an upregulation of COL1A1, COL3A1, 
and MMP2 mRNA levels in SM 28 days after overfeeding, with no changes in MMP9. Microarray-based tests revealed alterations in pathways related to ECM receptor interactions, focal adhesion and adherens junction, elucidating new evidence linking SM ECM remodeling and obesity-related insulin resistance [159]. Insulin sensitivity and inflammation occur in SM in obesity by increasing immune cell infiltration and proinflammatory activation in intermyocellular and perimuscular adipose tissue. Moreover, macrophages participate in SM repair and regeneration by modulating inflammation, stem cells, cytokines, growth factors, and ECM. Indeed, endurance exercise training induces changes in M2 macrophages, which are positively associated with changes in ECM genes and decreased IL6 expression after training [160].

Overall, microarrays and transcriptomic technologies have identified the role of several genes in adipose and SM ECM processes and structures and their implication in the different cell signaling pathways, which are disturbed in obesity and cause diverse complications in the metabolic homeostasis, and therefore, in the systemic metabolism.

\section{Conclusions and Further Perspectives}

Omics-based technologies and biomarkers provide a great advance in our knowledge on the etiology of diseases, including obesity ant its metabolic complications; and this brings considerable potential in identifying effective public health strategies that pave the way towards patient stratification and precision prevention [161]. Since the 1970s, evidence on genetic origins of obesity uncovered that the pathogenesis of obesity is far more complex than just a dysregulation of energy balance, highlighting the importance of the geneenvironment interactions by epigenetic modifications. In this context, novel etiological insights and targets are discovered through the omics approaches in order to understand the molecular mechanism of adipose and muscle ECM remodeling in obesity. Indeed, adipose tissue and muscle ECM remodeling plays a crucial role in the local and systemic metabolism, and understanding the crosstalk between both metabolic tissues is a challenge to develop new strategies against obesity. Here, we show, by exploring genomic (GWAS) epigenomic (EWAS) and transcriptomic (RNA-seq and cDNA microarrays) analysis, that TCF7L2 is one of the top ECM-related loci associated with T2D risk and obesity. Interestingly, a reported sequence variation, DNA methylation (observed in three different studies) and differential gene expression of the TCF7L2 region in SAT has been identified. Hence, TCF7L2 loci in adipose tissue may have an impact in diabetes susceptibility and inflammation. Furthermore, important genes implicated in adipocyte metabolism such as ADIPOQ, CD36, PPARG, and IL6 exhibit genetic and epigenetic patterns associated with obesity in adipose tissue. We also found genetic variations and differential gene expression in adipose tissue for ECM genes such as SIRT1, a NAD-dependent deacetylase involved in cellular regulation. Finally, a hyper-methylation of COL5A1 in VAT of women with insulin resistance was reported and a different gene expression pattern in VAT was also observed (Figure 1). Given the importance of muscle ECM regulating the insulin sensitivity and systemic metabolism, omics studies should address the molecular mechanism behind that in obesity. Nevertheless, according to the evidence encountered during the review, SM omics approaches are scarce. Despite the current evidence of genomic approaches in adipose tissue, still further studies are needed and larger prospective cohorts to validate findings and determine biomarkers, and even more in the case of SM. 


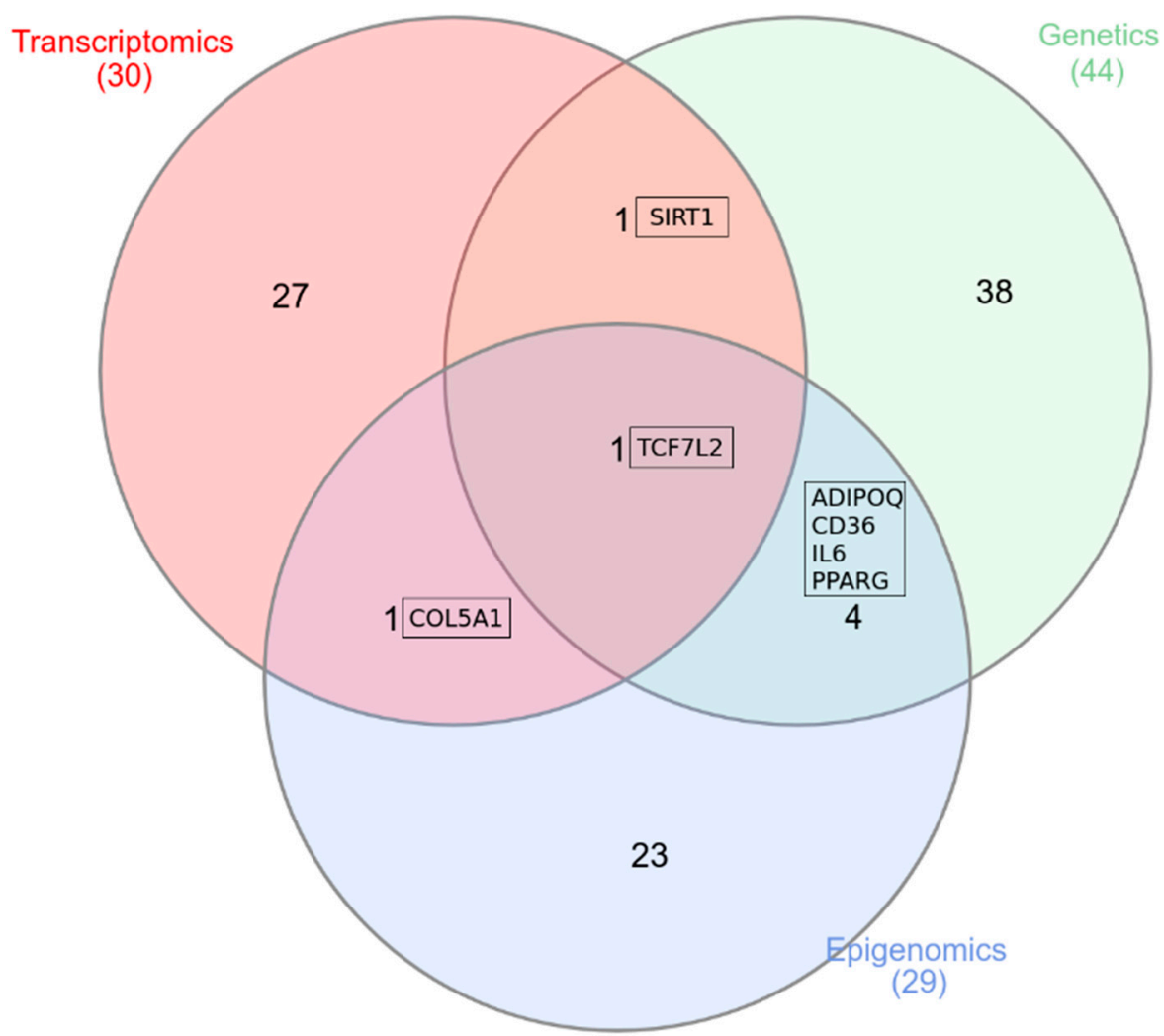

Figure 1. Venn diagram collecting the genes reported in omics approaches in adipose tissue. This figure shows the overlapping between genetics, epigenomics, and transcriptomic unveiling the role of ECM loci in obesity and metabolic comorbidities. ADIPOQ, adiponectin, $1 \mathrm{Q}$, and collagen domain-containing; $C D 36$, cluster of differentiation 36; COL5A1, collagen type V alpha 1 chain; IL6, interleukin-6; PPARG, peroxisome proliferator-activated receptor gamma; SIRT1, sirtuin-1; TCF7L2, transcription factor 7 like 2 .

Supplementary Materials: The following are available online at https:/ / www.mdpi.com/1422-006 7/22/5/2756/s1.

Author Contributions: All data was obtained by two investigators (A.A.-R. and M.B.-A.) and crosschecked by five investigators (A.A.-R., M.B.-A., J.A.-F., F.J.R.-O. and J.P.-D.). A.A.-R., M.B.-A., J.P.-D., J.A.-F., C.M.A., and F.J.R.-O. design the work and discussion. A.A.-R., M.B.-A., J.P.-D., A.M.-G., C.M.A., and F.J.R.-O. wrote of the manuscript. A.A.-R., M.B.-A., J.P.-D., J.A.-F., C.M.A., and F.J.R.-O. revised the manuscript. All authors have read and agreed to the published version of the manuscript.

Funding: This research received no external funding.

Institutional Review Board Statement: Not applicable.

Informed Consent Statement: Not applicable.

Data Availability Statement: Data sharing not applicable. No new data were created or analyzed in this study. Data sharing is not applicable to this article.

Acknowledgments: AMG is supported by a doctorate fellowship Formación del Profesorado Universitario (FPU 16/03653)", which is being completed as part of the Nutrition and Food Sciences Program at the University of Granada, Spain. AAR is supported by a doctorate contract i-PFIS: Doctorados IIS-empresa en ciencias y tecnologías de la salud (IFI17/00048). JPD is supported by a grant to postdoctoral researchers at foreign Universities and Research Centers from the "Ramón-Areces Foundation", Spain. FJRO is part of the "Personal Investigador Doctor", University of Granada, funded by Junta de Andalucía (PAIDI, 2020).

Conflicts of Interest: The authors declare no conflict of interest. 


\section{References}

1. Schoettl, T.; Fischer, I.P.; Ussar, S. Heterogeneity of adipose tissue in development and metabolic function. J. Exp. Biol. 2018, 221 (Suppl. 1), jeb162958. [CrossRef]

2. Sun, K.; Kusminski, C.M.; Scherer, P.E. Adipose tissue remodeling and obesity. J. Clin. Invest. 2011, 121, 2094-2101. [CrossRef]

3. Sun, K.; Tordjman, J.; Clement, K.; Scherer, P.E. Fibrosis and adipose tissue dysfunction. Cell Metab. 2013, 18, 470-477. [CrossRef]

4. Ruiz-Ojeda, F.J.; Méndez-Gutiérrez, A.; Aguilera, C.M.; Plaza-Díaz, J. Extracellular Matrix Remodeling of Adipose Tissue in Obesity and Metabolic Diseases. Int. J. Mol. Sci. 2019, 20, 4888. [CrossRef]

5. Cox, T.R.; Erler, J.T. Remodeling and homeostasis of the extracellular matrix: Implications for fibrotic diseases and cancer. Dis. Model. Mech. 2011, 4, 165-178. [CrossRef]

6. Lin, D.; Chun, T.H.; Kang, L. Adipose extracellular matrix remodelling in obesity and insulin resistance. Biochem. Pharm. 2016, 119, 8-16. [CrossRef]

7. Williams, A.S.; Kang, L.; Wasserman, D.H. The extracellular matrix and insulin resistance. Trends Endocrinol. Metab. 2015, 26, 357-366. [CrossRef]

8. Ruiz-Ojeda, F.J.; Wang, J.; Backer, T.; Krueger, M.; Zamani, S.; Rosowski, S.; Gruber, T.; Onogi, Y.; Feuchtinger, A.; Schulz, T.J.; et al. Active integrins regulate white adipose tissue insulin sensitivity and brown fat thermogenesis. Mol. Metab. 2021, 101147. [CrossRef]

9. Bluher, M. Are there still healthy obese patients? Curr. Opin. Endocrinol. Diabetes Obes. 2012, 19, 341-346. [CrossRef]

10. Mazzali, G.; Di Francesco, V.; Zoico, E.; Fantin, F.; Zamboni, G.; Benati, C.; Bambara, V.; Negri, M.; Bosello, O.; Zamboni, M. Interrelations between fat distribution, muscle lipid content, adipocytokines, and insulin resistance: Effect of moderate weight loss in older women. Am. J. Clin. Nutr. 2006, 84, 1193-1199. [CrossRef]

11. Guillet, C.; Delcourt, I.; Rance, M.; Giraudet, C.; Walrand, S.; Bedu, M.; Duche, P.; Boirie, Y. Changes in basal and insulin and amino acid response of whole body and skeletal muscle proteins in obese men. J. Clin. Endocrinol. Metab. 2009, 94, 3044-3050. [CrossRef]

12. Richardson, D.K.; Kashyap, S.; Bajaj, M.; Cusi, K.; Mandarino, S.J.; Finlayson, J.; DeFronzo, R.A.; Jenkinson, C.P.; Mandarino, L.J. Lipid Infusion Decreases the Expression of Nuclear Encoded Mitochondrial Genes and Increases the Expression of Extracellular Matrix Genes in Human Skeletal Muscle. J. Biol. Chem. 2005, 280, 10290-10297. [CrossRef]

13. Berria, R.; Wang, L.; Richardson, D.K.; Finlayson, J.; Belfort, R.; Pratipanawatr, T.; De Filippis, E.A.; Kashyap, S.; Mandarino, L.J. Increased collagen content in insulin-resistant skeletal muscle. Am. J. Physiol Endocrinol. Metab 2006, 290, E560-E565. [CrossRef]

14. Van Dijk, S.J.; Tellam, R.L.; Morrison, J.L.; Muhlhausler, B.S.; Molloy, P.L. Recent developments on the role of epigenetics in obesity and metabolic disease. Clin. Epigenet. 2015, 7, 66. [CrossRef]

15. Davegardh, C.; Garcia-Calzon, S.; Bacos, K.; Ling, C. DNA methylation in the pathogenesis of type 2 diabetes in humans. Mol. Metab. 2018, 14, 12-25. [CrossRef] [PubMed]

16. Ling, C.; Ronn, T. Epigenetics in Human Obesity and Type 2 Diabetes. Cell Metab. 2019, 29, 1028-1044. [CrossRef] [PubMed]

17. Gancheva, S.; Ouni, M.; Jelenik, T.; Koliaki, C.; Szendroedi, J.; Toledo, F.G.S.; Markgraf, D.F.; Pesta, D.H.; Mastrototaro, L.; De Filippo, E.; et al. Dynamic changes of muscle insulin sensitivity after metabolic surgery. Nat. Commun. 2019, 10, 4179. [CrossRef]

18. Moher, D.; Liberati, A.; Tetzlaff, J.; Altman, D.G.; Prisma Group. Preferred Reporting Items for Systematic Reviews and Meta-Analyses: The PRISMA Statement. PLoS Med. 2009, 6, e1000097. [CrossRef]

19. Shamseer, L.; Moher, D.; Clarke, M.; Ghersi, D.; Liberati, A.; Petticrew, M.; Shekelle, P.; Stewart, L.A. Preferred reporting items for systematic review and meta-analysis protocols (PRISMA-P) 2015: Elaboration and explanation. BMJ Br. Med. J. 2015 , 349 , g7647. [CrossRef]

20. Nakajima, I.; Yamaguchi, T.; Ozutsumi, K.; Aso, H. Adipose tissue extracellular matrix: Newly organized by adipocytes during differentiation. Differentiation 1998, 63, 193-200. [CrossRef]

21. Mori, S.; Kiuchi, S.; Ouchi, A.; Hase, T.; Murase, T. Characteristic expression of extracellular matrix in subcutaneous adipose tissue development and adipogenesis; comparison with visceral adipose tissue. Int. J. Biol. Sci. 2014, 10, 825-833. [CrossRef]

22. Poltavets, V.; Kochetkova, M.; Pitson, S.M.; Samuel, M.S. The Role of the Extracellular Matrix and Its Molecular and Cellular Regulators in Cancer Cell Plasticity. Front. Oncol. 2018, 8, 431. [CrossRef]

23. Liu, X.; Xu, Q.; Liu, W.; Yao, G.; Zhao, Y.; Xu, F.; Hayashi, T.; Fujisaki, H.; Hattori, S.; Tashiro, S.-I.; et al. Enhanced migration of murine fibroblast-like 3T3-L1 preadipocytes on type I collagen-coated dish is reversed by silibinin treatment. Mol. Cell. Biochem. 2018, 441, 35-62. [CrossRef]

24. Mariman, E.C.M.; Wang, P. Adipocyte extracellular matrix composition, dynamics and role in obesity. Cell. Mol. Life Sci. 2010, 67, 1277-1292. [CrossRef]

25. Huber, J.; Löffler, M.; Bilban, M.; Reimers, M.; Kadl, A.; Todoric, J.; Zeyda, M.; Geyeregger, R.; Schreiner, M.; Weichhart, T.; et al. Prevention of high-fat diet-induced adipose tissue remodeling in obese diabetic mice by n-3 polyunsaturated fatty acids. Int. J. Obes. 2007, 31, 1004-1013. [CrossRef]

26. Nagase, H.; Visse, R.; Murphy, G. Structure and function of matrix metalloproteinases and TIMPs. Cardiovasc. Res. 2006, 69, 562-573. [CrossRef]

27. Bourboulia, D.; Stetler-Stevenson, W.G. Matrix metalloproteinases (MMPs) and tissue inhibitors of metalloproteinases (TIMPs): Positive and negative regulators in tumor cell adhesion. Semin. Cancer Biol. 2010, 20, 161-168. [CrossRef] 
28. Maquoi, E.; Munaut, C.; Colige, A.; Collen, D.; Lijnen, H.R. Modulation of Adipose Tissue Expression of Murine Matrix Metalloproteinases and Their Tissue Inhibitors with Obesity. Diabetes 2002, 51, 1093-1101. [CrossRef]

29. Miksztowicz, V.; Morales, C.; Zago, V.; Friedman, S.; Schreier, L.; Berg, G. Effect of insulin-resistance on circulating and adipose tissue MMP-2 and MMP-9 activity in rats fed a sucrose-rich diet. Nutr. Metab. Cardiovasc. Dis. 2014, 24, 294-300. [CrossRef]

30. Murphy, G. Tissue inhibitors of metalloproteinases. Genome Biol. 2011, 12, 233. [CrossRef]

31. Hopps, E.; Lo Presti, R.; Montana, M.; Noto, D.; Averna, M.R.; Caimi, G. Gelatinases and their tissue inhibitors in a group of subjects with metabolic syndrome. J. Investig. Med. 2013, 61, 978-983. [CrossRef]

32. Jaworski, D.M.; Sideleva, O.; Stradecki, H.M.; Langlois, G.D.; Habibovic, A.; Satish, B.; Tharp, W.G.; Lausier, J.; LaRock, K.; Jetton, T.L.; et al. Sexually Dimorphic Diet-Induced Insulin Resistance in Obese Tissue Inhibitor of Metalloproteinase-2 (TIMP-2)Deficient Mice. Endocrinology 2011, 152, 1300-1313. [CrossRef]

33. Duarte, F.O.; Gomes-Gatto, C.D.V.; Oishi, J.C.; Lino, A.D.D.S.; Stotzer, U.S.; Rodrigues, M.F.C.; Gatti da Silva, G.H.; Selistre-de-Araújo, H.S. Physical training improves visceral adipose tissue health by remodelling extracellular matrix in rats with estrogen absence: A gene expression analysis. Int. J. Exp. Pathol. 2017, 98, 203-213. [CrossRef]

34. Frontera, W.R.; Ochala, J. Skeletal muscle: A brief review of structure and function. Calcif. Tissue Int. 2015, 96, 183-195. [CrossRef]

35. Gillies, A.R.; Lieber, R.L. Structure and function of the skeletal muscle extracellular matrix. Muscle Nerve 2011, 44, 318-331. [CrossRef]

36. Martinez-Huenchullan, S.; McLennan, S.V.; Verhoeven, A.; Twigg, S.M.; Tam, C.S. The emerging role of skeletal muscle extracellular matrix remodelling in obesity and exercise. Obes. Rev. 2017, 18, 776-790. [CrossRef]

37. Light, N.; Champion, A.E. Characterization of muscle epimysium, perimysium and endomysium collagens. Biochem. J. 1984, 219, 1017-1026. [CrossRef]

38. Marvulli, D.; Volpin, D.; Bressan, G.M. Spatial and temporal changes of type VI collagen expression during mouse development. Dev. Dyn. 1996, 206, 447-454. [CrossRef]

39. Weng, X.; Lin, D.; Huang, J.T.J.; Stimson, R.H.; Wasserman, D.H.; Kang, L. Collagen $24 \alpha 1$ Is Increased in Insulin-Resistant Skeletal Muscle and Adipose Tissue. Int. J. Mol. Sci. 2020, 21, 5738. [CrossRef]

40. Alameddine, H.S.; Morgan, J.E. Matrix Metalloproteinases and Tissue Inhibitor of Metalloproteinases in Inflammation and Fibrosis of Skeletal Muscles. J. Neuromuscul. Dis. 2016, 3, 455-473. [CrossRef]

41. Kang, L.; Mayes, W.H.; James, F.D.; Bracy, D.P.; Wasserman, D.H. Matrix metalloproteinase 9 opposes diet-induced muscle insulin resistance in mice. Diabetologia 2014, 57, 603-613. [CrossRef]

42. Knoblauch, A.; Will, C.; Goncharenko, G.; Ludwig, S.; Wixler, V. The binding of Mss4 to alpha-integrin subunits regulates matrix metalloproteinase activation and fibronectin remodeling. FASEB J. 2007, 21, 497-510. [CrossRef]

43. Liu, J.; DeYoung, S.M.; Zhang, M.; Zhang, M.; Cheng, A.; Saltiel, A.R. Changes in integrin expression during adipocyte differentiation. Cell Metab. 2005, 2, 165-177. [CrossRef]

44. Zong, H.; Bastie, C.C.; Xu, J.; Fassler, R.; Campbell, K.P.; Kurland, I.J.; Pessin, J.E. Insulin resistance in striated muscle-specific integrin receptor beta1-deficient mice. J. Biol. Chem. 2009, 284, 4679-4688. [CrossRef] [PubMed]

45. Kang, L.; Ayala, J.E.; Lee-Young, R.S.; Zhang, Z.; James, F.D.; Neufer, P.D.; Pozzi, A.; Zutter, M.M.; Wasserman, D.H. Diet-Induced Muscle Insulin Resistance Is Associated with Extracellular Matrix Remodeling and Interaction with Integrin $\alpha_{2} \beta_{1}$ in Mice. Diabetes 2011, 60, 416-426. [CrossRef] [PubMed]

46. Pessentheiner, A.R.; Quach, A.; Al-Azzam, N.; Liu, S.; Downes, M.; Evans, R.M.; Gordts, P.L.M.S. Adipose tissue heparan sulfate proteoglycans-Critical regulators of adipocyte metabolism and glucose homeostasis. FASEB J. 2020, 34 (Suppl. 1), 1. [CrossRef]

47. Brandan, E.; Gutierrez, J. Role of skeletal muscle proteoglycans during myogenesis. Matrix Biol. 2013, 32, 289-297. [CrossRef]

48. Kamiya, S.; Kato, R.; Wakabayashi, M.; Tohyama, T.; Enami, I.; Ueki, M.; Yajima, H.; Ishii, T.; Nakamura, H.; Katayama, T.; et al. Fibronectin peptides derived from two distinct regions stimulate adipocyte differentiation by preventing fibronectin matrix assembly. Biochemistry 2002, 41, 3270-3277. [CrossRef]

49. Kühl, U.; Öcalan, M.; Timpl, R.; von der Mark, K. Role of laminin and fibronectin in selecting myogenic versus fibrogenic cells from skeletal muscle cells in vitro. Dev. Biol. 1986, 117, 628-635. [CrossRef]

50. Leshem, Y.; Spicer, D.B.; Gal-Levi, R.; Halevy, O. Hepatocyte growth factor (HGF) inhibits skeletal muscle cell differentiation: A role for the bHLH protein twist and the cdk inhibitor p27. J. Cell Physiol. 2000, 184, 101-109. [CrossRef]

51. Saiki, A.; Watanabe, F.; Murano, T.; Miyashita, Y.; Shirai, K. Hepatocyte growth factor secreted by cultured adipocytes promotes tube formation of vascular endothelial cells in vitro. Int. J. Obes. 2006, 30, 1676-1684. [CrossRef]

52. Adachi, H.; Kurachi, H.; Homma, H.; Adachi, K.; Imai, T.; Morishige, K.; Matsuzawa, Y.; Miyake, A. Epidermal growth factor promotes adipogenesis of 3T3-L1 cell in vitro. Endocrinology 1994, 135, 1824-1830. [CrossRef]

53. Leroy, M.C.; Perroud, J.; Darbellay, B.; Bernheim, L.; Konig, S. Epidermal growth factor receptor down-regulation triggers human myoblast differentiation. PLoS ONE 2013, 8, e71770. [CrossRef]

54. Miyata, S.; Yada, T.; Ishikawa, N.; Taheruzzaman, K.; Hara, R.; Matsuzaki, T.; Nishikawa, A. Insulin-like growth factor 1 regulation of proliferation and differentiation of Xenopus laevis myogenic cells in vitro. In Vitro Cell. Dev. Biol. Anim. 2017, 53, $231-247$. [CrossRef] [PubMed]

55. Garten, A.; Schuster, S.; Kiess, W. The insulin-like growth factors in adipogenesis and obesity. Endocrinol. Metab. Clin. N. Am. 2012, 41, 283-295. [CrossRef] [PubMed] 
56. Prelle, K.; Wobus, A.M.; Krebs, O.; Blum, W.F.; Wolf, E. Overexpression of Insulin-like Growth Factor-II in Mouse Embryonic Stem Cells Promotes Myogenic Differentiation. Biochem. Biophys. Res. Commun. 2000, 277, 631-638. [CrossRef] [PubMed]

57. Zhang, K.; Wang, F.; Huang, J.; Lou, Y.; Xie, J.; Li, H.; Cao, D.; Huang, X. Insulin-like growth factor 2 promotes the adipogenesis of hemangioma-derived stem cells. Exp. Ther. Med. 2019, 17, 1663-1669. [CrossRef] [PubMed]

58. Lilla, J.; Stickens, D.; Werb, Z. Metalloproteases and adipogenesis: A weighty subject. Am. J. Pathol. 2002, 160, 1551-1554. [CrossRef]

59. Chen, X.; Li, Y. Role of matrix metalloproteinases in skeletal muscle: Migration, differentiation, regeneration and fibrosis. Cell Adh. Migr. 2009, 3, 337-341. [CrossRef]

60. Ahmad, K.; Choi, I.; Lee, Y.H. Implications of Skeletal Muscle Extracellular Matrix Remodeling in Metabolic Disorders: Diabetes Perspective. Int. J. Mol. Sci. 2020, 21, 3845. [CrossRef]

61. Ghanemi, A.; Melouane, A.; Yoshioka, M.; St-Amand, J. Secreted protein acidic and rich in cysteine and bioenergetics: Extracellular matrix, adipocytes remodeling and skeletal muscle metabolism. Int. J. Biochem. Cell Biol. 2019, 117, 105627. [CrossRef] [PubMed]

62. Fox, C.S.; Heard-Costa, N.; Cupples, L.A.; Dupuis, J.; Vasan, R.S.; Atwood, L.D. Genome-wide association to body mass index and waist circumference: The Framingham Heart Study 100K project. BMC Med. Genet. 2007, 8 (Suppl. 1), S18. [CrossRef] [PubMed]

63. León-Mimila, P.; Villamil-Ramírez, H.; Villalobos-Comparán, M.; Villarreal-Molina, T.; Romero-Hidalgo, S.; López-Contreras, B.; Gutiérrez-Vidal, R.; Vega-Badillo, J.; Jacobo-Albavera, L.; Posadas-Romeros, C.; et al. Contribution of common genetic variants to obesity and obesity-related traits in mexican children and adults. PLOS ONE 2013, 8, e70640.

64. Hinney, A.; Albayrak, Ö.; Antel, J.; Volckmar, A.-L.; Sims, R.; Chapman, J.; Harold, D.; Gerrish, A.; Heid, I.M.; Winkler, T.W.; et al. Genetic variation at the CELF1 (CUGBP, elav-like family member 1 gene) locus is genome-wide associated with Alzheimer's disease and obesity. Am. J. Med. Genet. Part. B Neuropsychiatr. Genet. 2014, 165, 283-293. [CrossRef] [PubMed]

65. Wang, J.; Ban, M.R.; Zou, G.Y.; Cao, H.; Lin, T.; Kennedy, B.A.; Anand, S.; Yusuf, S.; Huff, M.W.; Pollex, R.L.; et al. Polygenic determinants of severe hypertriglyceridemia. Hum. Mol. Genet. 2008, 17, 2894-2899. [CrossRef]

66. Chiang, K.-M.; Chang, H.-C.; Yang, H.-C.; Chen, C.-H.; Chen, H.-H.; Lee, W.-J.; Pan, W.-H. Genome-wide association study of morbid obesity in Han Chinese. BMC Genet. 2019, 20, 97. [CrossRef]

67. Comuzzie, A.G.; Cole, S.A.; Laston, S.L.; Voruganti, V.S.; Haack, K.; Gibbs, R.A.; Butte, N.F. Novel Genetic Loci Identified for the Pathophysiology of Childhood Obesity in the Hispanic Population. PLoS ONE 2012, 7, e51954. [CrossRef]

68. Namjou, B.; Keddache, M.; Marsolo, K.; Wagner, M.; Lingren, T.; Cobb, B.; Perry, C.; Kennebeck, S.; Holm, I.; Li, R.; et al. EMR-linked GWAS study: Investigation of variation landscape of loci for body mass index in children. Front. Genet. 2013, 4, 268. [CrossRef]

69. Pei, Y.-F.; Zhang, L.; Liu, Y.; Li, J.; Shen, H.; Liu, Y.-Z.; Tian, Q.; He, H.; Wu, S.; Ran, S.; et al. Meta-analysis of genome-wide association data identifies novel susceptibility loci for obesity. Hum. Mol. Genet. 2013, 23, 820-830. [CrossRef]

70. Wu, Y.; Duan, H.; Tian, X.; Xu, C.; Wang, W.; Jiang, W.; Pang, Z.; Zhang, D.; Tan, Q. Genetics of Obesity Traits: A Bivariate Genome-Wide Association Analysis. Front. Genet. 2018, 9, 179. [CrossRef]

71. Naukkarinen, J.; Surakka, I.; Pietiläinen, K.H.; Rissanen, A.; Salomaa, V.; Ripatti, S.; Yki-Järvinen, H.; van Duijn, C.M.; Wichmann, H.E.; Kaprio, J.; et al. Use of Genome-Wide Expression Data to Mine the "Gray Zone" of GWA Studies Leads to Novel Candidate Obesity Genes. PLoS Genet. 2010, 6, e1000976. [CrossRef]

72. Li, W.-D.; Jiao, H.; Wang, K.; Zhang, C.K.; Glessner, J.T.; Grant, S.F.A.; Zhao, H.; Hakonarson, H.; Arlen Price, R. A genome wide association study of plasma uric acid levels in obese cases and never-overweight controls. Obesity 2013, 21, E490-E494. [CrossRef]

73. Liu, H.Y.; Alyass, A.; Abadi, A.; Peralta-Romero, J.; Suarez, F.; Gomez-Zamudio, J.; Audirac, A.; Parra, E.J.; Cruz, M.; Meyre, D. Fine-mapping of 98 obesity loci in Mexican children. Int. J. Obes. 2019, 43, 23-32. [CrossRef]

74. Zhao, W.; Wineinger, N.E.; Tiwari, H.K.; Mosley, T.H.; Broeckel, U.; Arnett, D.K.; Kardia, S.L.R.; Kabagambe, E.K.; Sun, Y.V. Copy Number Variations Associated with Obesity-Related Traits in African Americans: A Joint Analysis between GENOA and HyperGEN. Obesity 2012, 20, 2431-2437. [CrossRef]

75. Liu, C.-T.; Monda, K.L.; Taylor, K.C.; Lange, L.; Demerath, E.W.; Palmas, W.; Wojczynski, M.K.; Ellis, J.C.; Vitolins, M.Z.; Liu, S.; et al. Genome-Wide Association of Body Fat Distribution in African Ancestry Populations Suggests New Loci. PLoS Genet. 2013, 9, e1003681. [CrossRef]

76. Felix, J.F.; Bradfield, J.P.; Monnereau, C.; van der Valk, R.J.P.; Stergiakouli, E.; Chesi, A.; Gaillard, R.; Feenstra, B.; Thiering, E.; Kreiner-Møller, E.; et al. Genome-wide association analysis identifies three new susceptibility loci for childhood body mass index. Hum. Mol. Genet. 2015, 25, 389-403. [CrossRef]

77. Kong, X.; Zhang, X.; Xing, X.; Zhang, B.; Hong, J.; Yang, W. The Association of Type 2 Diabetes Loci Identified in Genome-Wide Association Studies with Metabolic Syndrome and Its Components in a Chinese Population with Type 2 Diabetes. PLoS ONE 2015, 10, e0143607. [CrossRef] [PubMed]

78. Jiao, H.; Wang, K.; Yang, F.; Grant, S.F.A.; Hakonarson, H.; Price, R.A.; Li, W.-D. Pathway-Based Genome-Wide Association Studies for Plasma Triglycerides in Obese Females and Normal-Weight Controls. PLoS ONE 2015, 10, e0134923. [CrossRef]

79. Strawbridge, R.J.; Dupuis, J.; Prokopenko, I.; Barker, A.; Ahlqvist, E.; Rybin, D.; Petrie, J.R.; Travers, M.E.; Bouatia-Naji, N.; Dimas, A.S.; et al. Genome-wide association identifies nine common variants associated with fasting proinsulin levels and provides new insights into the pathophysiology of type 2 diabetes. Diabetes 2011, 60, 2624-2634. [CrossRef] 
80. Choquet, H.; Labrune, Y.; De Graeve, F.; Hinney, A.; Hebebrand, J.; Scherag, A.; Lecoeur, C.; Tauber, M.; Balkau, B.; Elliot, P.; et al. Lack of association of CD36 SNPs with early onset obesity: A meta-analysis in 9,973 European subjects. Obesity (Silver Spring) 2011, 19, 833-839. [CrossRef] [PubMed]

81. Ng, M.C.; Hester, J.M.; Wing, M.R.; Li, J.; Xu, J.; Hicks, P.J.; Roh, B.H.; Lu, L.; Divers, J.; Langefeld, C.D.; et al. Genome-wide association of BMI in African Americans. Obesity 2012, 20, 622-627. [CrossRef]

82. Wilson, C.L.; Liu, W.; Yang, J.J.; Kang, G.; Ojha, R.P.; Neale, G.A.; Srivastava, D.K.; Gurney, J.G.; Hudson, M.M.; Robison, L.L.; et al. Genetic and clinical factors associated with obesity among adult survivors of childhood cancer: A report from the St. Jude Lifetime Cohort. Cancer 2015, 121, 2262-2270. [CrossRef]

83. Kocarnik, J.M.; Pendergrass, S.A.; Carty, C.L.; Pankow, J.S.; Schumacher, F.R.; Cheng, I.; Durda, P.; Ambite, J.L.; Deelman, E.; Cook, N.R.; et al. Multiancestral analysis of inflammation-related genetic variants and C-reactive protein in the population architecture using genomics and epidemiology study. Circ. Cardiovasc. Genet. 2014, 7, 178-188. [CrossRef]

84. Ortega-Azorín, C.; Coltell, O.; Asensio, E.M.; Sorlí, J.V.; González, J.I.; Portolés, O.; Saiz, C.; Estruch, R.; Ramírez-Sabio, J.B.; Pérez-Fidalgo, A.; et al. Candidate Gene and Genome-Wide Association Studies for Circulating Leptin Levels Reveal Population and Sex-Specific Associations in High Cardiovascular Risk Mediterranean Subjects. Nutrients 2019, 11, 2751. [CrossRef]

85. Hotta, K.; Kitamoto, A.; Kitamoto, T.; Mizusawa, S.; Teranishi, H.; Matsuo, T.; Nakata, Y.; Hyogo, H.; Ochi, H.; Nakamura, T.; et al. Genetic variations in the CYP17A1 and NT5C2 genes are associated with a reduction in visceral and subcutaneous fat areas in Japanese women. J. Hum. Genet. 2012, 57, 46-51. [CrossRef]

86. Demerath, E.W.; Liu, C.-T.; Franceschini, N.; Chen, G.; Palmer, J.R.; Smith, E.N.; Chen, C.T.L.; Ambrosone, C.B.; Arnold, A.M.; Bandera, E.V.; et al. Genome-wide association study of age at menarche in African-American women. Hum. Mol. Genet. 2013, 22, 3329-3346. [CrossRef] [PubMed]

87. Gao, C.; Wang, N.; Guo, X.; Ziegler, J.T.; Taylor, K.D.; Xiang, A.H.; Hai, Y.; Kridel, S.J.; Nadler, J.L.; Kandeel, F.; et al. A Comprehensive Analysis of Common and Rare Variants to Identify Adiposity Loci in Hispanic Americans: The IRAS Family Study (IRASFS). PLoS ONE 2015, 10, e0134649. [CrossRef] [PubMed]

88. Hong, K.-W.; Chung, M.; Cho, S.B. Meta-analysis of genome-wide association study of homeostasis model assessment $\beta$ cell function and insulin resistance in an East Asian population and the European results. Mol. Genet. Genom. 2014, 289, 1247-1255. [CrossRef] [PubMed]

89. Rinella, E.S.; Still, C.; Shao, Y.; Wood, G.C.; Chu, X.; Salerno, B.; Gerhard, G.S.; Ostrer, H. Genome-wide Association of SingleNucleotide Polymorphisms with Weight Loss Outcomes After Roux-en-Y Gastric Bypass Surgery. J. Clin. Endocrinol. Metab. 2013, 98, E1131-E1136. [CrossRef] [PubMed]

90. Jones, M.R.; Brower, M.A.; Xu, N.; Cui, J.; Mengesha, E.; Chen, Y.-D.I.; Taylor, K.D.; Azziz, R.; Goodarzi, M.O. Systems Genetics Reveals the Functional Context of PCOS Loci and Identifies Genetic and Molecular Mechanisms of Disease Heterogeneity. PLoS Genet. 2015, 11, e1005455. [CrossRef]

91. Sarzynski, M.A.; Jacobson, P.; Rankinen, T.; Carlsson, B.; Sjöström, L.; Bouchard, C.; Carlsson, L.M. Associations of markers in 11 obesity candidate genes with maximal weight loss and weight regain in the SOS bariatric surgery cases. Int. J. Obes. 2011, 35, 676-683. [CrossRef] [PubMed]

92. Wang, K.; Li, W.-D.; Zhang, C.K.; Wang, Z.; Glessner, J.T.; Grant, S.F.A.; Zhao, H.; Hakonarson, H.; Price, R.A. A Genome-Wide Association Study on Obesity and Obesity-Related Traits. PLoS ONE 2011, 6, e18939. [CrossRef] [PubMed]

93. Warrington, N.M.; Howe, L.D.; Paternoster, L.; Kaakinen, M.; Herrala, S.; Huikari, V.; Wu, Y.Y.; Kemp, J.P.; Timpson, N.J.; Pourcain, B.S.; et al. A genome-wide association study of body mass index across early life and childhood. Int. J. Epidemiol. 2015, 44, 700-712. [CrossRef] [PubMed]

94. Liu, Y.-J.; Liu, X.-G.; Wang, L.; Dina, C.; Yan, H.; Liu, J.-F.; Levy, S.; Papasian, C.J.; Drees, B.M.; Hamilton, J.J.; et al. Genome-wide association scans identified CTNNBL1 as a novel gene for obesity. Hum. Mol. Genet. 2008, 17, 1803-1813. [CrossRef] [PubMed]

95. Scuteri, A.; Sanna, S.; Chen, W.-M.; Uda, M.; Albai, G.; Strait, J.; Najjar, S.; Nagaraja, R.; Orrú, M.; Usala, G.; et al. Genome-Wide Association Scan Shows Genetic Variants in the FTO Gene Are Associated with Obesity-Related Traits. PLoS Genet. 2007,3 , e115. [CrossRef]

96. Salinas, Y.D.; Wang, L.; DeWan, A.T. Multiethnic genome-wide association study identifies ethnic-specific associations with body mass index in Hispanics and African Americans. BMC Genet. 2016, 17, 78. [CrossRef]

97. Bian, L.; Traurig, M.; Hanson, R.L.; Marinelarena, A.; Kobes, S.; Muller, Y.L.; Malhotra, A.; Huang, K.; Perez, J.; Gale, A.; et al. MAP2K3 is associated with body mass index in American Indians and Caucasians and may mediate hypothalamic inflammation. Hum. Mol. Genet. 2013, 22, 4438-4449. [CrossRef]

98. Wei, F.J.; Cai, C.Y.; Yu, P.; Lv, J.; Ling, C.; Shi, W.T.; Jiao, H.X.; Chang, B.C.; Yang, F.H.; Tian, Y.; et al. Quantitative candidate gene association studies of metabolic traits in Han Chinese type 2 diabetes patients. Genet. Mol. Res. 2015, 14, 15471-15481. [CrossRef]

99. Dorajoo, R.; Blakemore, A.I.; Sim, X.; Ong, R.T.; Ng, D.P.; Seielstad, M.; Wong, T.Y.; Saw, S.M.; Froguel, P.; Liu, J.; et al. Replication of 13 obesity loci among Singaporean Chinese, Malay and Asian-Indian populations. Int. J. Obes. 2012, 36, 159-163. [CrossRef]

100. Hong, K.W.; Oh, B. Recapitulation of genome-wide association studies on body mass index in the Korean population. Int. J. Obes. 2012, 36, 1127-1130. [CrossRef]

101. Lv, D.; Zhang, D.D.; Wang, H.; Zhang, Y.; Liang, L.; Fu, J.F.; Xiong, F.; Liu, G.L.; Gong, C.X.; Luo, F.H.; et al. Genetic variations in SEC16B, MC4R, MAP2K5 and KCTD15 were associated with childhood obesity and interacted with dietary behaviors in Chinese school-age population. Gene 2015, 560, 149-155. [CrossRef] 
102. Mei, H.; Chen, W.; Jiang, F.; He, J.; Srinivasan, S.; Smith, E.N.; Schork, N.; Murray, S.; Berenson, G.S. Longitudinal replication studies of GWAS risk SNPs influencing body mass index over the course of childhood and adulthood. PLoS ONE 2012, 7, e31470. [CrossRef]

103. Wang, H.J.; Hinney, A.; Song, J.Y.; Scherag, A.; Meng, X.R.; Grallert, H.; Illig, T.; Hebebrand, J.; Wang, Y.; Ma, J. Association of common variants identified by recent genome-wide association studies with obesity in Chinese children: A case-control study. BMC Med. Genet. 2016, 17, 7. [CrossRef]

104. Wen, W.; Cho, Y.S.; Zheng, W.; Dorajoo, R.; Kato, N.; Qi, L.; Chen, C.H.; Delahanty, R.J.; Okada, Y.; Tabara, Y.; et al. Meta-analysis identifies common variants associated with body mass index in east Asians. Nat. Genet. 2012, 44, 307-311. [CrossRef]

105. Hebebrand, J.; Peters, T.; Schijven, D.; Hebebrand, M.; Grasemann, C.; Winkler, T.W.; Heid, I.M.; Antel, J.; Föcker, M.; Tegeler, L.; et al. The role of genetic variation of human metabolism for BMI, mental traits and mental disorders. Mol. Metab. 2018, 12, 1-11. [CrossRef]

106. Chen, G.; Bentley, A.; Adeyemo, A.; Shriner, D.; Zhou, J.; Doumatey, A.; Huang, H.; Ramos, E.; Erdos, M.; Gerry, N.; et al. Genome-wide association study identifies novel loci association with fasting insulin and insulin resistance in African Americans. Hum. Mol. Genet. 2012, 21, 4530-4536. [CrossRef] [PubMed]

107. Corfitsen, H.T.; Krantz, B.; Larsen, A.; Drago, A. Molecular pathway analysis associates alterations in obesity-related genes and antipsychotic-induced weight gain. Acta Neuropsychiatr. 2020, 32, 72-83. [CrossRef] [PubMed]

108. Cao, M.; Zhang, L.; Chen, T.; Shi, A.; Xie, K.; Li, Z.; Xu, J.; Chen, Z.; Ji, C.; Wen, J. Genetic Susceptibility to Gestational Diabetes Mellitus in a Chinese Population. Front. Endocrinol. 2020, 11, 247. [CrossRef]

109. Kim, H.J.; Yoo, Y.J.; Ju, Y.S.; Lee, S.; Cho, S.I.; Sung, J.; Kim, J.I.; Seo, J.S. Combined linkage and association analyses identify a novel locus for obesity near PROX1 in Asians. Obesity 2013, 21, 2405-2412. [CrossRef] [PubMed]

110. Dong, Y.; Guo, T.; Traurig, M.; Mason, C.C.; Kobes, S.; Perez, J.; Knowler, W.C.; Bogardus, C.; Hanson, R.L.; Baier, L.J. SIRT1 is associated with a decrease in acute insulin secretion and a sex specific increase in risk for type 2 diabetes in Pima Indians. Mol. Genet. Metab. 2011, 104, 661-665. [CrossRef]

111. Jung, S.Y.; Scott, P.A.; Papp, J.C.; Sobel, E.M.; Pellegrini, M.; Yu, H.; Han, S.; Zhang, Z.F. Genome-wide Association Analysis of Proinflammatory Cytokines and Gene-lifestyle Interaction for Invasive Breast Cancer Risk: The WHI dbGaP Study. Cancer Prev. Res. 2020, 14, 41-54. [CrossRef] [PubMed]

112. Speakman, J.R. Functional Analysis of Seven Genes Linked to Body Mass Index and Adiposity by Genome-Wide Association Studies: A Review. Hum. Hered. 2013, 75, 57-79. [CrossRef]

113. Vogel, C.I.G.; Greene, B.; Scherag, A.; Müller, T.D.; Friedel, S.; Grallert, H.; Heid, I.M.; Illig, T.; Wichmann, H.E.; Schäfer, H.; et al. Non-replication of an association of CTNNBL1polymorphisms and obesity in a population of Central European ancestry. BMC Med. Genet. 2009, 10, 14. [CrossRef] [PubMed]

114. Hoggart, C.J.; Venturini, G.; Mangino, M.; Gomez, F.; Ascari, G.; Zhao, J.H.; Teumer, A.; Winkler, T.W.; Tšernikova, N.; Luan, J.A.; et al. Novel Approach Identifies SNPs in SLC2A10 and KCNK9 with Evidence for Parent-of-Origin Effect on Body Mass Index. PLoS Genet. 2014, 10, e1004508. [CrossRef]

115. Perfilyev, A.; Dahlman, I.; Gillberg, L.; Rosqvist, F.; Iggman, D.; Volkov, P.; Nilsson, E.; Riserus, U.; Ling, C. Impact of polyunsaturated and saturated fat overfeeding on the DNA-methylation pattern in human adipose tissue: A randomized controlled trial. Am. J. Clin. Nutr. 2017, 105, 991-1000. [CrossRef]

116. Guenard, F.; Tchernof, A.; Deshaies, Y.; Biron, S.; Lescelleur, O.; Biertho, L.; Marceau, S.; Perusse, L.; Vohl, M.C. Genetic regulation of differentially methylated genes in visceral adipose tissue of severely obese men discordant for the metabolic syndrome. Transl. Res. 2017, 184, 1-11. [CrossRef] [PubMed]

117. Crujeiras, A.B.; Diaz-Lagares, A.; Moreno-Navarrete, J.M.; Sandoval, J.; Hervas, D.; Gomez, A.; Ricart, W.; Casanueva, F.F.; Esteller, M.; Fernandez-Real, J.M. Genome-wide DNA methylation pattern in visceral adipose tissue differentiates insulin-resistant from insulin-sensitive obese subjects. Transl. Res. 2016, 178, 13-24. [CrossRef] [PubMed]

118. Crujeiras, A.B.; Pissios, P.; Moreno-Navarrete, J.M.; Diaz-Lagares, A.; Sandoval, J.; Gomez, A.; Ricart, W.; Esteller, M.; Casanueva, F.F.; Fernandez-Real, J.M. An Epigenetic Signature in Adipose Tissue Is Linked to Nicotinamide N-Methyltransferase Gene Expression. Mol. Nutr. Food Res. 2018, 62, e1700933. [CrossRef]

119. Demerath, E.W.; Guan, W.; Grove, M.L.; Aslibekyan, S.; Mendelson, M.; Zhou, Y.H.; Hedman, A.K.; Sandling, J.K.; Li, L.A.; Irvin, M.R.; et al. Epigenome-wide association study (EWAS) of BMI, BMI change and waist circumference in African American adults identifies multiple replicated loci. Hum. Mol. Genet. 2015, 24, 4464-4479. [CrossRef]

120. Ronn, T.; Volkov, P.; Gillberg, L.; Kokosar, M.; Perfilyev, A.; Jacobsen, A.L.; Jorgensen, S.W.; Brons, C.; Jansson, P.A.; Eriksson, K.F.; et al. Impact of age, BMI and HbA1c levels on the genome-wide DNA methylation and mRNA expression patterns in human adipose tissue and identification of epigenetic biomarkers in blood. Hum. Mol. Genet. 2015, 24, 3792-3813. [CrossRef]

121. Anguita-Ruiz, A.; Mendez-Gutierrez, A.; Ruperez, A.I.; Leis, R.; Bueno, G.; Gil-Campos, M.; Tofe, I.; Gomez-Llorente, C.; Moreno, L.A.; Gil, A.; et al. The protein S100A4 as a novel marker of insulin resistance in prepubertal and pubertal children with obesity. Metabolism 2020, 105, 154187. [CrossRef]

122. Nilsson, E.; Jansson, P.A.; Perfilyev, A.; Volkov, P.; Pedersen, M.; Svensson, M.K.; Poulsen, P.; Ribel-Madsen, R.; Pedersen, N.L.; Almgren, P.; et al. Altered DNA methylation and differential expression of genes influencing metabolism and inflammation in adipose tissue from subjects with type 2 diabetes. Diabetes 2014, 63, 2962-2976. [CrossRef] 
123. Ronn, T.; Volkov, P.; Davegardh, C.; Dayeh, T.; Hall, E.; Olsson, A.H.; Nilsson, E.; Tornberg, A.; Dekker Nitert, M.; Eriksson, K.F.; et al. A six months exercise intervention influences the genome-wide DNA methylation pattern in human adipose tissue. PLoS Genet. 2013, 9, e1003572. [CrossRef]

124. Multhaup, M.L.; Seldin, M.M.; Jaffe, A.E.; Lei, X.; Kirchner, H.; Mondal, P.; Li, Y.; Rodriguez, V.; Drong, A.; Hussain, M.; et al. Mouse-human experimental epigenetic analysis unmasks dietary targets and genetic liability for diabetic phenotypes. Cell Metab. 2015, 21, 138-149. [CrossRef] [PubMed]

125. Bollepalli, S.; Kaye, S.; Heinonen, S.; Kaprio, J.; Rissanen, A.; Virtanen, K.A.; Pietilainen, K.H.; Ollikainen, M. Subcutaneous adipose tissue gene expression and DNA methylation respond to both short- and long-term weight loss. Int. J. Obes. 2018, 42, 412-423. [CrossRef]

126. Arner, P.; Sahlqvist, A.S.; Sinha, I.; Xu, H.; Yao, X.; Waterworth, D.; Rajpal, D.; Loomis, A.K.; Freudenberg, J.M.; Johnson, T.; et al. The epigenetic signature of systemic insulin resistance in obese women. Diabetologia 2016, 59, 2393-2405. [CrossRef]

127. Keller, M.; Hopp, L.; Liu, X.; Wohland, T.; Rohde, K.; Cancello, R.; Klos, M.; Bacos, K.; Kern, M.; Eichelmann, F.; et al. Genomewide DNA promoter methylation and transcriptome analysis in human adipose tissue unravels novel candidate genes for obesity. Mol. Metab. 2017, 6, 86-100. [CrossRef] [PubMed]

128. Andersen, E.; Ingerslev, L.R.; Fabre, O.; Donkin, I.; Altintas, A.; Versteyhe, S.; Bisgaard, T.; Kristiansen, V.B.; Simar, D.; Barres, R. Preadipocytes from obese humans with type 2 diabetes are epigenetically reprogrammed at genes controlling adipose tissue function. Int. J. Obes. 2019, 43, 306-318. [CrossRef] [PubMed]

129. Kamei, Y.; Suganami, T.; Ehara, T.; Kanai, S.; Hayashi, K.; Yamamoto, Y.; Miura, S.; Ezaki, O.; Okano, M.; Ogawa, Y. Increased expression of DNA methyltransferase 3a in obese adipose tissue: Studies with transgenic mice. Obesity 2010, 18, 314-321. [CrossRef]

130. Gillberg, L.; Perfilyev, A.; Brøns, C.; Thomasen, M.; Grunnet, L.G.; Volkov, P.; Rosqvist, F.; Iggman, D.; Dahlman, I.; Risérus, U.; et al. Adipose tissue transcriptomics and epigenomics in low birthweight men and controls: Role of high-fat overfeeding. Diabetologia 2016, 59, 799-812. [CrossRef] [PubMed]

131. Zhang, X.; Gu, H.F.; Frystyk, J.; Efendic, S.; Brismar, K.; Thorell, A. Analyses of IGFBP2 DNA methylation and mRNA expression in visceral and subcutaneous adipose tissues of obese subjects. Growth Horm. IGF Res. 2019, 45, 31-36. [CrossRef]

132. Petrus, P.; Bialesova, L.; Checa, A.; Kerr, A.; Naz, S.; Backdahl, J.; Gracia, A.; Toft, S.; Dahlman-Wright, K.; Heden, P.; et al. Adipocyte Expression of SLC19A1 Links DNA Hypermethylation to Adipose Tissue Inflammation and Insulin Resistance. J. Clin. Endocrinol. Metab. 2018, 103, 710-721. [CrossRef]

133. Ryden, M.; Petrus, P.; Andersson, D.P.; Medina-Gomez, G.; Escasany, E.; Corrales Cordon, P.; Dahlman, I.; Kulyte, A.; Arner, P. Insulin action is severely impaired in adipocytes of apparently healthy overweight and obese subjects. J. Intern. Med. 2019, 285, 578-588. [CrossRef] [PubMed]

134. Dayeh, T.; Tuomi, T.; Almgren, P.; Perfilyev, A.; Jansson, P.-A.; de Mello, V.D.; Pihlajamäki, J.; Vaag, A.; Groop, L.; Nilsson, E.; et al. DNA methylation of loci within ABCG1 and PHOSPHO1 in blood DNA is associated with future type 2 diabetes risk. Epigenetics 2016, 11, 482-488. [CrossRef] [PubMed]

135. Tsai, P.-C.; Glastonbury, C.A.; Eliot, M.N.; Bollepalli, S.; Yet, I.; Castillo-Fernandez, J.E.; Carnero-Montoro, E.; Hardiman, T.; Martin, T.C.; Vickers, A.; et al. Smoking induces coordinated DNA methylation and gene expression changes in adipose tissue with consequences for metabolic health. Clin. Epigenet. 2018, 10, 126. [CrossRef]

136. Chu, S.H.; Kelsey, K.T.; Koestler, D.C.; Loucks, E.B.; Huang, Y.T. Leveraging cell-specific differentially methylated regions to identify leukocyte infiltration in adipose tissue. Genet. Epidemiol. 2019, 43, 1018-1029. [CrossRef]

137. De Toro-Martín, J.; Guénard, F.; Tchernof, A.; Deshaies, Y.; Pérusse, L.; Biron, S.; Lescelleur, O.; Biertho, L.; Marceau, S.; Vohl, M.C. A CpG-SNP Located within the ARPC3 Gene Promoter Is Associated with Hypertriglyceridemia in Severely Obese Patients. Ann. Nutr. Metab. 2016, 68, 203-212. [CrossRef] [PubMed]

138. Bluher, M. Adipose tissue inflammation: A cause or consequence of obesity-related insulin resistance? Clin. Sci. 2016, 130, 1603-1614. [CrossRef] [PubMed]

139. Shimobayashi, M.; Albert, V.; Woelnerhanssen, B.; Frei, I.C.; Weissenberger, D.; Meyer-Gerspach, A.C.; Clement, N.; Moes, S.; Colombi, M.; Meier, J.A.; et al. Insulin resistance causes inflammation in adipose tissue. J. Clin. Investig. 2018, 128, 1538-1550. [CrossRef]

140. Lagathu, C.; Christodoulides, C.; Tan, C.Y.; Virtue, S.; Laudes, M.; Campbell, M.; Ishikawa, K.; Ortega, F.; Tinahones, F.J.; Fernández-Real, J.M.; et al. Secreted frizzled-related protein 1 regulates adipose tissue expansion and is dysregulated in severe obesity. Int. J. Obes. 2010, 34, 1695-1705. [CrossRef] [PubMed]

141. Wang, C.; Ha, X.; Li, W.; Xu, P.; Zhang, Z.; Wang, T.; Li, J.; Wang, Y.; Li, S.; Xie, J.; et al. Comparative gene expression profile and DNA methylation status in diabetic patients of Kazak and Han people. Medicine 2018, 97, e11982. [CrossRef]

142. Schadt, E.E.; Monks, S.A.; Drake, T.A.; Lusis, A.J.; Che, N.; Colinayo, V.; Ruff, T.G.; Milligan, S.B.; Lamb, J.R.; Cavet, G.; et al. Genetics of gene expression surveyed in maize, mouse and man. Nature 2003, 422, 297-302. [CrossRef] [PubMed]

143. Bolton, J.; Montastier, E.; Carayol, J.; Bonnel, S.; Mir, L.; Marques, M.A.; Astrup, A.; Saris, W.; Iacovoni, J.; Villa-Vialaneix, N.; et al. Molecular Biomarkers for Weight Control in Obese Individuals Subjected to a Multiphase Dietary Intervention. J. Clin. Endocrinol. Metab. 2017, 102, 2751-2761. [CrossRef] [PubMed] 
144. Hong, X.; Hao, K.; Ji, H.; Peng, S.; Sherwood, B.; Di Narzo, A.; Tsai, H.-J.; Liu, X.; Burd, I.; Wang, G.; et al. Genome-wide approach identifies a novel gene-maternal pre-pregnancy BMI interaction on preterm birth. Nat. Commun. 2017, 8, 15608. [CrossRef] [PubMed]

145. Liu, Y.; Aron-Wisnewsky, J.; Marcelin, G.; Genser, L.; Le Naour, G.; Torcivia, A.; Bauvois, B.; Bouchet, S.; Pelloux, V.; Sasso, M.; et al. Accumulation and Changes in Composition of Collagens in Subcutaneous Adipose Tissue After Bariatric Surgery. J. Clin. Endocrinol. Metab. 2016, 101, 293-304. [CrossRef]

146. Pettersson, M.; Viljakainen, H.; Loid, P.; Mustila, T.; Pekkinen, M.; Armenio, M.; Andersson-Assarsson, J.C.; Mäkitie, O.; Lindstrand, A. Copy Number Variants Are Enriched in Individuals with Early-Onset Obesity and Highlight Novel Pathogenic Pathways. J. Clin. Endocrinol. Metab. 2017, 102, 3029-3039. [CrossRef]

147. Pellegrinelli, V.; Heuvingh, J.; du Roure, O.; Rouault, C.; Devulder, A.; Klein, C.; Lacasa, M.; Clément, E.; Lacasa, D.; Clément, K. Human adipocyte function is impacted by mechanical cues. J. Pathol. 2014, 233, 183-195. [CrossRef] [PubMed]

148. Tokunaga, M.; Inoue, M.; Jiang, Y.; Barnes, R.H., II; Buchner, D.A.; Chun, T.-H. Fat depot-specific gene signature and ECM remodeling of Sca1(high) adipose-derived stem cells. Matrix Biol. 2014, 36, 28-38. [CrossRef]

149. Li, X.; Thomason, P.A.; Withers, D.J.; Scott, J. Bio-informatics analysis of a gene co-expression module in adipose tissue containing the diet-responsive gene Nnat. BMC Syst. Biol. 2010, 4, 175. [CrossRef]

150. Aguilera, C.M.; Gomez-Llorente, C.; Tofe, I.; Gil-Campos, M.; Cañete, R.; Gil, Á. Genome-wide expression in visceral adipose tissue from obese prepubertal children. Int. J. Mol. Sci. 2015, 16, 7723-7737. [CrossRef]

151. Kępczyńska, M.A.; Zaibi, M.S.; Alomar, S.Y.; Trayhurn, P. PCR arrays indicate that the expression of extracellular matrix and cell adhesion genes in human adipocytes is regulated by IL-1 $\beta$ (interleukin-1 $\beta$ ). Arch. Physiol. Biochem. 2017, 123, 61-67. [CrossRef] [PubMed]

152. Kogelman, L.J.; Fu, J.; Franke, L.; Greve, J.W.; Hofker, M.; Rensen, S.S.; Kadarmideen, H.N. Inter-Tissue Gene Co-Expression Networks between Metabolically Healthy and Unhealthy Obese Individuals. PLoS ONE 2016, 11, e0167519. [CrossRef] [PubMed]

153. De Oliveira, M.; De Sibio, M.T.; Mathias, L.S.; Rodrigues, B.M.; Sakalem, M.E.; Nogueira, C.R. Irisin modulates genes associated with severe coronavirus disease (COVID-19) outcome in human subcutaneous adipocytes cell culture. Mol. Cell. Endocrinol. 2020, 515, 110917. [CrossRef]

154. Samuvel, D.J.; Sundararaj, K.P.; Li, Y.; Lopes-Virella, M.F.; Huang, Y. Adipocyte-mononuclear cell interaction, Toll-like receptor 4 activation, and high glucose synergistically up-regulate osteopontin expression via an interleukin 6-mediated mechanism. J. Biol. Chem. 2010, 285, 3916-3927. [CrossRef] [PubMed]

155. Wu, C. Focal adhesion: A focal point in current cell biology and molecular medicine. Cell Adh. Migr. 2007, 1, 13-18. [CrossRef] [PubMed]

156. Luk, C.T.; Shi, S.Y.; Cai, E.P.; Sivasubramaniyam, T.; Krishnamurthy, M.; Brunt, J.J.; Schroer, S.A.; Winer, D.A.; Woo, M. FAK signalling controls insulin sensitivity through regulation of adipocyte survival. Nat. Commun. 2017, 8, 14360. [CrossRef]

157. Liu, Y.; Ji, Y.; Li, M.; Wang, M.; Yi, X.; Yin, C.; Wang, S.; Zhang, M.; Zhao, Z.; Xiao, Y. Integrated analysis of long noncoding RNA and mRNA expression profile in children with obesity by microarray analysis. Sci. Rep. 2018, 8, 8750. [CrossRef] [PubMed]

158. Tam, C.S.; Covington, J.D.; Bajpeyi, S.; Tchoukalova, Y.; Burk, D.; Johannsen, D.L.; Zingaretti, C.M.; Cinti, S.; Ravussin, E. Weight Gain Reveals Dramatic Increases in Skeletal Muscle Extracellular Matrix Remodeling. J. Clin. Endocrinol. Metab. 2014, 99, 1749-1757. [CrossRef]

159. Tam, C.S.; Chaudhuri, R.; Hutchison, A.T.; Samocha-Bonet, D.; Heilbronn, L.K. Skeletal muscle extracellular matrix remodeling after short-term overfeeding in healthy humans. Metabolism 2017, 67, 26-30. [CrossRef]

160. Walton, R.G.; Kosmac, K.; Mula, J.; Fry, C.S.; Peck, B.D.; Groshong, J.S.; Finlin, B.S.; Zhu, B.; Kern, P.A.; Peterson, C.A. Human skeletal muscle macrophages increase following cycle training and are associated with adaptations that may facilitate growth. Sci. Rep. 2019, 9, 969. [CrossRef]

161. Aleksandrova, K.; Egea Rodrigues, C.; Floegel, A.; Ahrens, W. Omics Biomarkers in Obesity: Novel Etiological Insights and Targets for Precision Prevention. Curr. Obes. Rep. 2020, 9, 219-230. [CrossRef] [PubMed] 